\title{
"I've Got a Little List": Spotifying Mitt Romney and Barack Obama in the 2012 U.S. Presidential Election
}

\section{DANA GORZELANY-MOSTAK}

During his 1992 presidential campaign rallies, Democratic candidate Bill Clinton frequently exited the dais to the strains of "Don't Stop," a song that perfectly captured the energy and youthful vitality of his campaign. Pre-existing songs like this 1977 Fleetwood Mac hit, which already made the rounds on record, radio, and television, became the gold standard for American presidential campaigns by the 1990s. ${ }^{1}$ Most Americans of voting age at the time will remember "Don't Stop" as the Arkansas governor's campaign theme song, but his senior strategist, Paul Begala, may have been thinking bigger with regards to preexisting music's role in campaign pageantry. Drawing a parallel with the soundtrack, Begala once claimed, "A presidential campaign is like a film ... It never comes together until it's scored and tracked." At his appearances, Clinton offered not only "Don't Stop" but also a larger campaign playlist comprised primarily of $\mathrm{R} \& \mathrm{~B}$, pop, and classic rock oldies that affirmed his political optimism, rootedness in the cultures and values of the past, and hip, retro tastes. Perhaps capitalizing on the nostalgia explosion in advertising and on screen at the time, Clinton's playlist evoked the safety and security of an imagined past for baby boomers, the cohort to which the candidate belongs. Clinton's team emphasized his small-town, Southern roots and branded him as the poster child of the '60s, so in this regard, the playlist tied into the nostalgic narratives that fomented around his candidacy, as well as his campaign platform and ideological orientation. ${ }^{3}$ And it is important to note that with his playlist of pre-existing songs and his own performance of Elvis Presley's "Heartbreak Hotel" on The Arsenio Hall Show, Clinton was constructing not merely his presidential identity but the identity of the American presidency as well. ${ }^{4}$

Like Clinton, numerous presidential candidates over the past twenty years have adopted the playlist strategy. Begala's analogy to film insinuates that a campaign playlist may be not just a hodgepodge of uplifting tunes but rather a thoughtfully organized cluster of songs intended to establish a presidential persona or brand, underscore or intensify a candidates' words and actions, and appeal to a specific demographic. Rallies, conventions, and, more recently, the music-streaming platform Spotify, have offered campaign playlists, constructing a diverse and multivalent soundscape that imbues old music with new

I would like to thank Remi Chiu, Melvin Backstrom, James Deaville, Joanna Love, Michael Saffle, and Felicia Miyakawa for their feedback on drafts of this article, and my research assistant Aaron Hock for his work investigating playlisting sites. I would also like to acknowledge Dickinson College for generously funding my trip to the 2013 Society for American Music conference where I presented an earlier version of this work.

${ }^{1}$ For more on the shift to "canned music," see Benjamin S. Schoening and Eric T. Kasper, Don't Stop Thinking about the Music: The Politics of Songs and Musicians in Presidential Campaigns (Lanham, MD: Lexington, 2012), chap. 5 and 6.

${ }^{2}$ Robert Costa, "Songs for Campaign Seasons Past and Present," Wall Street Fournal, October 2, 2008, http://online.wsj.com/article/SB122290103509796055.html.

${ }^{3}$ Philip Abbott, “A 'Long and Winding Road': Bill Clinton and the 1960s," Rhetoric Eง Public Affairs 9, no. 1 (2006): 1-20.

${ }^{4}$ For more on the Clinton-Elvis connection, see Greil Marcus, Double Trouble: Bill Clinton and Elvis Presley in a Land of No Alternatives (New York: Picador, 2001); and "The Elvis Strategy," New York Times, October 27, 1992,

http://www.nytimes.com/1992/10/27/opinion/the-elvis-strategy.html. 
political and cultural significance. As widely circulated, popular texts, pre-existing songs can signify on multiple levels; they offer up rich histories, associated cultural texts, a complex web of intra- and extramusical connotations, a body of criticism, and communities already culturally invested in them. And, as Richard Middleton posits, discourses about songs, genres, and artists (who maintain their own star personas, fan bases, political orientations, and histories) can equally contribute to the constitution of musical meaning. ${ }^{5}$

The campaign music analyst can comment on the function and signifying potential of individual songs, but an appraisal of presidential playlists and the discourses they precipitate as a whole might offer additional insight into how candidates deploy the products of popular culture to sell themselves and galvanize their supporters. And with the boundary between the political field and pop cultural field effaced, a candidate's cultural competence-to use Pierre Bourdieu's term-can be understood as a form of political competence, and music-aesthetic disposition can provide a window into a candidate's political values. ${ }^{6}$ At the same time, the analysis of campaign-themed playlists created by online users might shed light on how the citizenry uses music to engage with individual candidates and the deliberative process. This article investigates the functions of the list in music and music-related discourses, as well as the cultural work lists can perform during campaign season. After providing a handful of examples from early twenty-first-century campaigns to illustrate these functions, I turn to Mitt Romney's and Barack Obama's 2012 playlists, focusing on Spotify and the public's reception to their respective engagements with musicsharing communities. To conclude, I consider the ways in which the campaign playlist serves as a tool for political communication, mobilization, and participation, and ponder its changing function in a 2.0 world.

\section{From Giovanni to Joel}

When we imagine lists, "shopping" or "to-do" lists-what semiotician Umberto Eco defines as practical (or pragmatic) lists-are often the first to come to mind, but lists can serve a variety of functions in creative as well as utilitarian musical contexts. Consider, for example, the roll call of lionized composers in Pierre Moulu's motet "Mater floreat," Don Giovanni's 2065 amorous conquests in Leporello's "Catalogue Aria" ("Madamina, il catalogo è questo"), and Ko-Ko the Lord High Executioner's hit list (the verse that gives this article its title) in Gilbert and Sullivan's operetta The Mikado. ${ }^{7}$ For a modern example from American pop music, we might consider Billy Joel's quasi-patter song, "We Didn't Start the Fire" (1989), as a poetic list of sorts with a memorializing function. The Piano Man rattles off in rapid succession dozens of personalities, milestone global events, scandals, and cultural products during the verses, then the song's choruses remind us that the list is still in progress and has no beginning or end: "We didn't start the fire / It was always burning / Since the world's been turning." Lists such as Joel's, which give a nod to the infinite and unknowable, offer what Eco calls a "topos of ineffability." If an author deals with a subject that is immense or possesses a depth of content that can never fully be known, he or

\footnotetext{
${ }^{5}$ Richard Middleton, "Introduction: Locating the Popular Music Text," in Reading Pop: Approaches to Textual Analysis in Popular Music, ed. Richard Middleton (Oxford: Oxford University Press, 2000), 1-19; and “From Me To You' Popular Music as Message," in Studying Popular Music (Milton Keynes, UK: Open University Press, 1990), 172-246.

${ }^{6}$ For more on cultural competence, see Pierre Bourdieu, Distinction: A Social Critique of the Fudgement of Taste, trans. Richard Nice (Cambridge, MA: Harvard University Press, 1984); and "The Forms of Capital," in Handbook of Theory and Research for the Sociology of Education, ed. John G. Richardson (New York: Greenwood, 1986), 241-58.

${ }^{7}$ Eco does briefly mention the Don Giovanni aria. See Umberto Eco, The Infinity of Lists: From Homer to foyce (London: MacLehose, 2009), 116-17. Ko-Ko’s aria is titled “As Some Day It May Happen.”
} 
she may propose a list "as a specimen, example, or indication, leaving the reader to imagine the rest." ${ }^{8}$ The eclecticism of the lyrics and Joel's delivery style indeed convey the list's "dizzying voraciousness." ${ }^{2}$ In this list, we do not hunt for specific information, but rather accept the singer's invitation to append our own meaning to the miscellany, his stream of consciousness-or to use Eco's term, "chaotic enumeration." To me, Joel's use of the word "fire" conjures up the image of Prometheus bestowing agency on humankind; humanity is the collective "we" that "didn't start the fire." Joel's lyrics (which offer an American-centric view of world history) and even Moulu's (which establish a musical canon) affirm Eco's claim that lists can be implicated in the creation of culture.

Fast forward five hundred years from Moulu, and the preoccupation with canon formation has not subsided. Lists such as the Billboard "Hot 100" or VH1's "100 Greatest Videos of All Time" are widely circulated, and as Liam Young noted in 2011, "recent years have seen a mass of countdowns, rankings, and 'best of the all-time' collections of cultural information steadily expand." Investigating functionality, literary theorist Robert E. Belknap argues the list can indeed serve as a vehicle for ranking but can be created "for other reasons as well-inventorying our possessions and taking the measure of ourselves, lumping and splitting, grouping and dividing the world about us, finding similarities and differences between things and creating patterns of possibility with them, making assessments of things that are important to us, memorializing the fallen, the lost, the loved." ${ }^{2}$ The "best of" lists that I cite above reflect the values of the mainstream's cultural gatekeepers, but individuals often create music lists of their own to fulfill Belknap's other functions. Take, for example, a consumer-driven list-building act that began in the analog age: the practice of curating material from one's own albums or favorite radio stations and creating mixtapes to be sold or swapped with others. Although digital formats have supplanted the cassette in the twenty-first century, the drive to remake, order, and reorder cultural artifacts or information in a way that satisfies one's own desires has only increased.

Such creative impulses may account for the popularity of BuzzFeed, a viral media hub that allows staff and users to generate their own lists of web-based videos, songs, and images. The site's "32 Ways to Tell You Grew Up in the Golden Age of Pop Punk" illustrates how lists can simultaneously assume both creative and utilitarian functions (Fig. 1). ${ }^{13}$ To the uninitiated, the list simply gives practical information, but to Gen-Xers with a penchant for mid-'90s nostalgia, the list affirms pop punk's authenticating space, establishes the central role of angst in its lyrical content, reifies its pantheon of artists, and documents its sartorial flare and visual style. In other words, the list inventories the performances and performative acts that define the genre (or exclude something from it) while memorializing its surrounding cultural practices and affirming their historical specificity. The pop punk list's coauthors may not be twenty-first-

\footnotetext{
${ }^{8}$ Ibid., 49.

${ }^{9}$ Eco uses this phrase to describe the verses on drink and money in the Carmina Burana (verses 196 and 11). Ibid., 137-41.

${ }^{10}$ Ibid., 321-52.

${ }^{11}$ Liam Cole Young, "The List and/as Critical Environment: Un-'Black Boxing' Bob Mersereau’s Top 100 Canadian Singles," paper presented at the annual meeting of the International Association for the Study of Popular Music-Canada, Montreal, QC, June 16-19, 2011, http://iaspm.ca/wp-content/uploads/2011/06/2011 liamyoung list mersereau.pdf. Also see the excellent article that extends the ideas presented in this paper, "Un-Black Boxing the List: Knowledge, Materiality, and Form," Canadian Fournal of Communication 38, no. 4 (2013): 497-516. Young correlates the "massive proliferation" of the online list in particular with the transition to an information society. See "On Lists and Networks: An Archaeology of Form," Amodern 2: Network Archaeology (2013), http://amodern.net/article/on-lists-and-networks.

${ }^{12}$ Robert E. Belknap, The List: The Uses and Pleasures of Cataloguing (New Haven: Yale University Press, 2004), xii.

${ }^{13}$ MelisBuzzFeed, Ashley Baccam, and Joe Puglisi, “32 Ways to Tell You Grew Up in the Golden Age of Pop Punk," BuzzFeed, August 28, 2013, http://www.buzzfeed.com/melismashable/32-ways-to-tell-you-grew-up-in-the-golden-age-of-poppunk.
} 
century Walt Whitmans, but their carefully curated content and pithy captions certainly demonstrate substantial creativity and insight. And indeed the list aspires to define the parameters of a specific cultural identity.

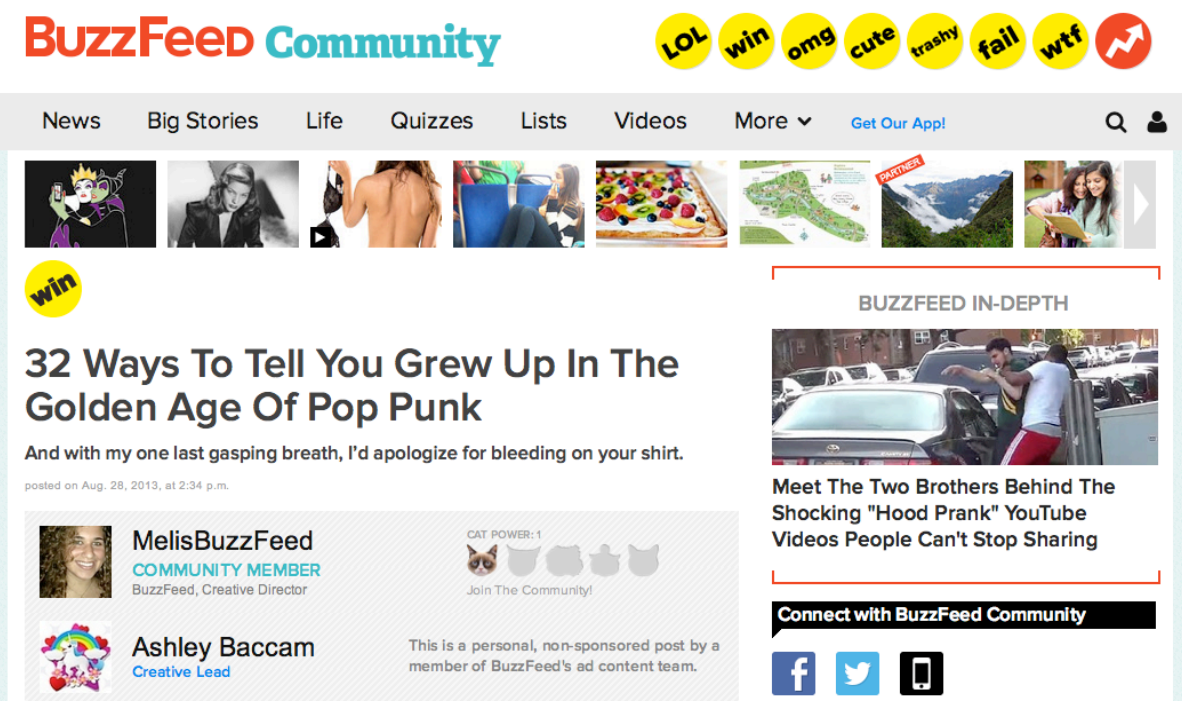

1. You always wanted to make a pilgrimage to Long Island...

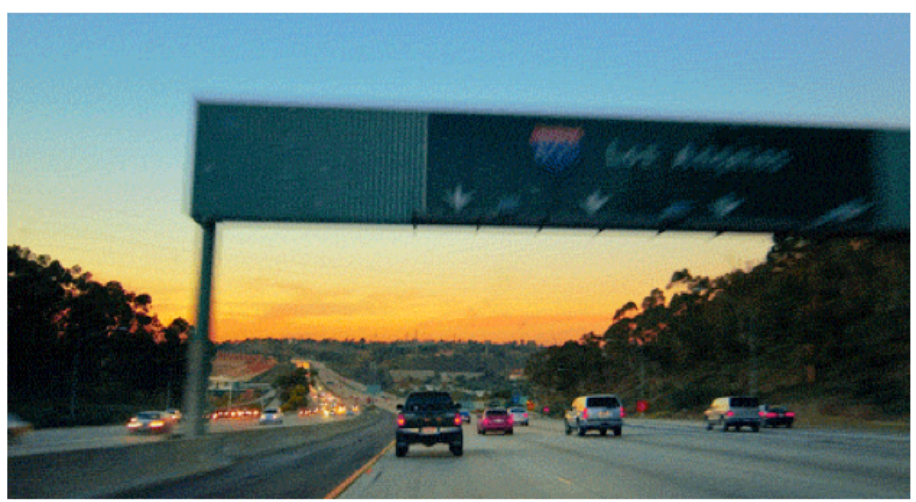

8. Either Blink-182 or Green Day started it all for you.

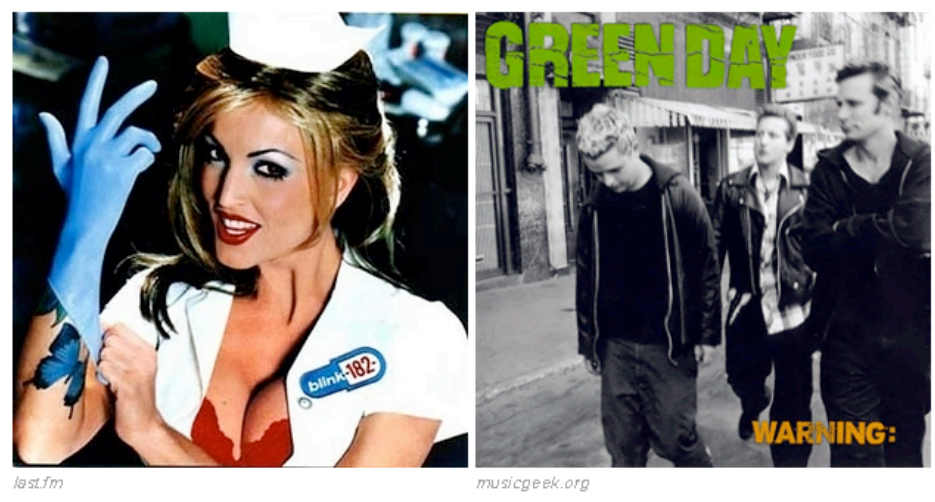

Figure 1: “32 Ways to Tell You Grew Up in the Golden Age of Pop Punk” (BuzzFeed) 
BuzzFeed is only one of countless sites where Internet users can fashion lists, whether it be lists of their own favorite songs (e.g., Listology, Listverse, and Ranker), or actual playlists (e.g., iTunes, Slacker Radio, and Spotify). The emergence of these sites illustrates another point germane to this study: advances in communication and media technologies, such as the proliferation of portable media devices, peer-topeer file sharing, networked communications infrastructure, and the interoperability of digital platforms, have transformed the public's engagement with music lists in the twenty-first century. ${ }^{14}$ Playlists of increasing length and diversity can be made, remade, "shuffled," and circulated by anyone. In our current "configurable culture," to use Aram Sinnreich's phrase, the digital list, with its inherent mutability, poses a challenge to notions of authority, authorship, and creativity as it becomes a dialogically constituted product of the digital age. The lack of materiality in digital files, Tom McCourt argues, heightens and intensifies the user's sense of "ownership" as well as his or her desire to customize. ${ }^{15}$ And users have a vast catalogue from which they can customize their lists. Spotify's tagline, "all music, all the time," is not an exaggeration. The site offers over 30 million songs and adds twenty thousand new songs on a daily basis. ${ }^{16}$ The use of playlisting platforms is widespread: Spotify reports over 60 million active users, Slacker Radio boasts 25 million registered users, and digital download giant Apple claims 800 million iTunes account users. ${ }^{17}$ In the twenty-first century, it seems like everyone has "got a little playlist.".

Mitt Romney and Barack Obama are no exceptions. Taking a cue from their constituents, the 2012 presidential hopefuls (and their respective teams) flexed their own curatorial muscles not only in live contexts, but in virtual ones as well. Reaffirming his identity as the "first Internet president," incumbent candidate Barack Obama announced the creation of his campaign playlist on Tumblr and Twitter, and released the list on Spotify in February of 2012. ${ }^{19}$ Not to be outdone, Republican opponent Mitt Romney tweeted a link to his own Spotify list in March. But the candidates were not alone in their respective quests to invent appealing campaign soundscapes. In response to the releases of the Romney and Obama Spotify playlists, the public penned their own fictional lists on the comment boards of various news pages and political websites, and created campaign-inspired playlists on Spotify as well as on other playlisting sites such as Grooveshark, 8tracks, and DatPiff. Tapping into the participatory dynamic of music-sharing platforms, Obama extended an invitation to his followers to make their own suggestions for airtime at his

\footnotetext{
${ }^{14}$ Aram Sinnreich, Mashed Up: Music, Technology, and the Rise of Configurable Culture (Amherst: University of Massachusetts Press, 2010), esp. chap. 3.

${ }^{15}$ Tom McCourt, "Collecting Music in the Digital Realm," Popular Music and Society 28, no. 2 (May 2005), 250.

16 "Information," Spotify, accessed June 15, 2015, http://press.spotify.com/us/information. With their computers, phones, or mobile devices, Spotify users can stream songs from any location. The site offers mobile iPhone and Android apps that allow users to sync playlists to multiple devices, and users can also purchase their playlists in MP3 format and sync them to their iPods. Integration with Facebook, Twitter, and Messenger allows Spotify users to share playlists with their social networks. If a Spotify user listens to a song, the song information and a link appear on their Facebook newsfeed; then, their friends can see what they are listening to and access the music themselves through Spotify's cloud-based player. See Trevor Essmeier, "Spotify: Pioneers in Cloud Technology," Fresh Consulting website, September 23, 2011, http://freshconsulting.com/spotifypioneers-in-cloud-technology.

17 "Information," Spotify; Harley Brown, "Slacker Radio CEO Duncan Orrell-Jones Wants to 'Reinvent Radio for a PostYouTube Era," Billboard, December 10, 2014, http://www.billboard.com/articles/news/6398461/slacker-radio-ceo-duncanorwell-reinvent-radio-post-youtube; Nina Ulloa, "iTunes Has 800 Million Accounts . . . and 800 Million Credit Card Numbers . . ” Digital Music News, April 24, 2014, http://www.digitalmusicnews.com/permalink/2014/04/24/itunes800m.

${ }^{18}$ For more on how technology has transformed the process of music distribution, see Steve Jones, "Music That Moves: Popular Music, Distribution and Network Technologies," Cultural Studies 16, no. 2 (2002): 213-32.

${ }_{19}^{19}$ Barack Obama Tumblr Page, February 9, 2012, http://barackobama.tumblr.com/post/17319836576/behold-the-2012campaign-playlist-on-spotify. Also see Kat George, "President Obama Releases His 28 Song Campaign Playlist on Spotify," VH1.com, February 9, 2012, http://www.vh1.com/music/tuner/2012-02-09/president-obama-releases-a-28-song-strongcampaign-playlist-on-spotify.
} 
rallies and debuted a second playlist of "supporter picks" in May.

Campaign lists in their many manifestations-the crowd-rousing rally list, the voter's own curated playlist, the inventory of a candidate's iPod, the fictional list posted on social media sites, and the candidate's playlist on Spotify-function as a form of social currency for citizens who create, listen to, and share music in the twenty-first century. Citizenship in the digital era, John Hartley argues, "is not simply the cerebral exercise of monitorial scrutiny; it is both a whole-of-body and a body-to-body experience, comedic and competitive, entertaining and festive, in the very performance of political deliberation and participation." ${ }^{20}$ Such "purposeful play," or in this case, purposeful playlisting, constitutes citizenship and may model new civic possibilities. ${ }^{21}$ In investigating lists, list-making activities, and list-related discourses as forms of civic participation in the 2012 campaign, we might ask the following questions: (1) How do the technologies of interactivity and configurability impact the form and contents of campaign playlists? (2) How do these technologies expand the function of campaign playlists, and the ways in which voters can interact with them?

\section{How to Do Things with Lists}

Music lists such as those that I have enumerated above indeed serve the myriad functions outlined by Belknap: these lists inventory ("Catalogue Aria"), rank (Billboard "Hot 100"), memorialize ("We Didn't Start the Fire"), make assessments ("Mater floreat"), or even perform a combination of these functions ("Pop Punk" on BuzzFeed). The list may serve three interrelated functions in campaign contexts. First, the candidate's own list-whether it be his list of favorite songs as cited in an interview, a rally playlist, or a Spotify playlist - may function as a declaration of musical taste that establishes image, values, and vision. In his landmark text Distinction, Bourdieu argues that taste is rooted in socioeconomic identity, and thus "taste classifies, and it classifies the classifier." ${ }^{22}$ In other words, just as specific cultural practices and institutions shape the coding of a musical work, the work itself carries the implications of a certain audience. Therefore, a candidate's cultural competence (knowledge or "feel for the game") might also allow him or her to establish a connection with a particular community (e.g., Bill Clinton appealed to baby boomers with his nostalgic playlist).

Second, the list may serve as an object of exchange between voter and candidate or among voting communities. In these contexts, music lists act as a form of social currency, a type of information or "buzz" about a candidate's brand that citizens can share as a part of their daily lives. ${ }^{23}$ Music-sharing sites offer the candidate a ready-made platform for engaging potential voters, and this extends beyond just the act of sharing the actual list. As Jeffrey P. Jones notes, popular culture offers voters a "language of expression" through which they can construct their own campaign narratives, make sense of the candidates' identities and ideologies, and affirm their respective roles in the democratic process. ${ }^{24}$ This voter-driven process can also be implicated in candidate identity formation-while we might speak about

\footnotetext{
${ }^{20}$ John Hartley, "Silly Citizenship,” Critical Discourse Studies 7, no. 4 (2010): 243-44.

${ }^{21}$ Ibid., 244.

${ }^{22}$ Bourdieu, Distinction, 6.

${ }^{23}$ The Vivaldi Partners Group, a consulting firm, defines social currency as "the extent to which people share the brand or information about the brand as part of their everyday social lives at work or at home.” Vivaldi Partners, \$ocial Currency Study, US 2010 (New York: Vivaldi Partners, 2010), 5, http://images.fastcompany.com/Vivald-iPartners Social-Currency.pdf.

${ }^{24}$ Jeffrey P. Jones, "The Shadow Campaign in Popular Culture," in The 2004 Presidential Campaign: A Communication

Perspective, ed. Robert E. Denton Jr. (Lanham: Rowman and Littlefield, 2005), 213-14.
} 
music's ability to accentuate certain attributes of the presidential subject, presidential identity, especially in the age of social media, is dialogically constituted through a series of negotiations and performative acts that occur over time. ${ }^{25}$

And third, participation in list creation and exchange offers voters a sense of both pleasure and empowerment. Between 2009 and 2012, I surveyed over four hundred college students on their listening habits. The undergraduates reported creating playlists based on their presumed activities, such as walking to class, working out, relaxing, or drinking (Anja Nylund Hagen calls these lists "context-sensitive playlists"). ${ }^{26}$ The students' surveys affirm Tia DeNora's contention that music allows persons to "regulate, elaborate, and substantiate themselves as social agents," but their responses also suggest that the curatorial process in and of itself is a pleasurable pastime that offers as much satisfaction as enjoying the end result of their labors. ${ }^{27}$ Students eagerly elaborated on the inner workings of their selection process-why certain songs fit together while others do not and how they go about curating the perfect list. In the age of mobile privatization, users can employ music as a means of structuring their sonic environment at will, and these acts, Michael Bull argues, empower listeners as they move though public spaces. ${ }^{28}$

We can see these three functions at work in the earlier campaigns of John McCain, Barack Obama, and Hillary Clinton. While the average iPod user may create playlists solely for their own enjoyment and face only the jeers of their friends, for the candidate, the wrong playlist, or even the wrong song, can have embarrassing consequences. During his 2000 presidential campaign, McCain chose "The Liberty Bell" march for a few rallies. Laughter ensued when attendees recognized John Philip Sousa's tune as the theme from the British sketch comedy series Monty Python's Flying Circus. ${ }^{29}$ While for McCain's team a Sousa march may have seemed an inclusive, safe, all-American choice, it unfortunately confirmed the candidate's ignorance of popular culture. In other words, a candidate's theme song, rally playlist, or response to the inquiry "What is on your iPod?" may lead voters to make certain assumptions based on the candidate's tastes. Competence in the area of music can help candidates convey a particular worldview or system of values - a habitus, so to speak. In this regard, McCain made a wiser choice in 2008 with the song "Gonna Fly Now" (1977) from the blockbuster film Rocky: the connotative thrust of the song and its association with the iconic pugilist nicely dovetailed with the contents of the candidate's speeches. In one October 2008 appearance in Pennsylvania, McCain told the crowd, "Fighting is what America is all about ... to love America is to fight for it." ${ }^{30}$ Indeed these remarks affirm what Katherine Adam and Charles Derber

\footnotetext{
${ }^{25}$ Dawn R. Gilpin notes the shift in focus from subject attributes to dialogic processes in studies of identity formation. See "Working in the Twittersphere: Microblogging as Professional Identity Construction," in A Networked Self: Identity, Community and Culture on Social Network Sites, ed. Zizi Papacharissi (New York: Routledge, 2011), 233.

${ }^{26}$ Anja Nylund Hagen, "The Playlist Experience: Personal Playlists in Music Streaming Services," Popular Music and Society (2015): 12-14.

${ }^{27}$ Tia DeNora, Music in Everyday Life (Cambridge: Cambridge University Press, 2000), 47.

${ }^{28}$ Michael Bull, "No Dead Air! The iPod and the Culture of Mobile Listening," Leisure Studies 24, no. 4 (2005): 345. Like Hagen, Bull addresses the use of playlists to create an aural space appropriate to a particular activity or to establish or reflect a certain mood. For more on mobile privatization, see Raymond Williams, Television: Technology and Cultural Form (New York: Schocken, 1975).

${ }^{29}$ Richard Roeper, "Keep on Rockin' in the Free World: Gore, Bush Try to Get in Tune with Young Voters," Chicago SunTimes, October 29, 2000, 4; Geoff Boucher, "Songs in the Key of Presidency," Los Angeles Times, October 11, 2000, http://articles.latimes.com/2000/oct/11/news/mn-34788/2.

${ }^{30}$ Michael A. Cohen, “McCain's Fight Song," Campaign Stops (blog), New York Times, October 19, 2008, http://campaignstops.blogs.nytimes.com/2008/10/19/mccains-fight-song. McCain also used another song from the Rocky film series, "Eye of the Tiger," which enflamed Survivor guitarist and songwriter Frankie Sullivan. See Natalie Finn, "Another Rocky Song Choice for John McCain,” E! Online, October 14, 2008, http://www.eonline.com/news/63813/another-rockysong-choice-for-john-mccain.
} 
call the "supermasculinized vision of international politics" that defined the Republican brand in $2008 .^{31}$ And, of course, the boxing world (as dramatized in the film) offered complementary rhetoric that explored the limits of competition, domination, and sacrifice. Whereas songs such as Brooks \& Dunn's "That's What It's All About" also appeared to be a good fit, McCain's playlist, on other occasions, provoked the ire of liberal-leaning acts, such as the Foo Fighters, John Mellencamp, and Boston, who disapproved of his use of their music. ${ }^{32}$

During the 2008 primaries, Obama's music preferences came up on several occasions. In one interview, he enumerated his music tastes as follows: "I'm old school, so generally, generally, I'm more of a jazz guy, a Miles Davis, a John Coltrane guy, more of a Marvin Gaye, Stevie Wonder kind of guy ... But having said that, I'm current enough that on my iPod I've got a little bit of Jay Z. I've got a little Beyoncé." 33 While he dropped the names of enough newer artists to appear hip, he emphasized his admiration for older, canonized black performers-performers whose histories and generic associations may have signaled to the voter the kind of presidency the Illinois senator would offer. Gaye and Wonder are connected with the legacy of Motown, a label that elevated black artists and promoted interracial harmony, and Davis and Coltrane are associated with innovations in jazz. Obama's musical tastes affirmed his connection to the black struggles of the '60s and '70s and his alliance with contemporary black communities, as well as hinted towards his values_human rights, equality, and civic mindedness. Adding to the perception of Obama's professed tastes as "authentic," many of the artists he cited as his personal favorites also earned a place on his rally playlists. Wonder's alliance with Obama did not raise many eyebrows, but Jay Z's did. Not surprisingly, too much cultural knowledge can also open up a candidate to trenchant criticism. In 2008, Republicans scoffed at Obama's status as a global celebrity, and as Joanna Love's work in this issue shows, political advertisements reasserted this fact during the 2012 electoral cycle.

The now defunct magazine Blender published lists of Obama's and McCain's top-ten favorite songs, and several news outlets printed the lists of songs that the candidates played on the campaign trail along with their feedback and, on some occasions, even analysis by music experts (Fig. 2). ${ }^{34}$ For their part,

\footnotetext{
${ }^{31}$ Katherine Adam and Charles Derber, The New Feminized Majority: How Democrats Can Change America with Women's Values (Boulder: Paradigm, 2008), 139.

${ }^{32}$ Sean Michaels, "Foo Fighters Slam John McCain Over Use of Song," Guardian, October 9, 2008, http://www.theguardian.com/music/2008/oct/09/foo.fighters.slam.john.mccain. See also Matthew J. Cursio, "Born To Be Used in the USA: An Alternative Avenue for Evaluating Politicians' Unauthorized Use of Original Musical Performances on the Campaign Trail," Villanova Sports E Entertainment Law Fournal 18 (2011): 317-71; and Kimberlianne Podlas, “Off the Campaign Trail and Into the Courthouse: Does a Political Candidate's Use of a Song Infringe on the Performer's Trademark?” Journal Of Broadcasting E Electronic Media 59, no. 1 (2015): 41-56.

${ }^{33}$ This statement from the June 2007 interview is cited in Peter Hamby, "Barack Obama Gets Name-Dropped in Hip-Hop," CNN, August 17, 2007, http://www.cnn.com/2007/POLITICS/08/17/obama.hip.hop/index.html. The candidate made similar comments to Vibe: "You know I haven't been buying new music lately. Because I don't have time. Look, I'm impacted by my generation. Most of my iPod probably is either jazz classics—Coltrane, Miles Davis—or it's got the songs of my youth, right? So you know Stevie Wonder, Earth, Wind \& Fire, Aretha Franklin.” Jeff Chang, "Barack Obama: The Vibe Interview," Vibe, August 2007, http://www.thelavinagency.com/content/speakers/58/1212688601_chang-vibe.pdf. See also Jann S. Wenner, “A Conversation With Barack Obama," Rolling Stone, July 10-24, 2008, http://www.jannswenner.com/Archives/Barack_Obama.aspx.

${ }^{34}$ Jon Coplon, "White House DJ Battle," Blender, July 30, 2008, https://web.archive.org/web/20080814151724/http://www.blender.com/WhiteHouseDJBattle/articles/39518.aspx. For an article that discusses Obama's 2008 rally playlist and offers an expert's analysis, see Margaret Talev, "Soul of the Obama Campaign Is in the Soundtrack," McClatchyDC.com, October 31, 2008, http://www.mcclatchydc.com/2008/10/31/55103/soul-of-the-obama-campaign-is.html\#.UjHixDn3DfY. The expert is Mark Anthony Neal, a professor of African and African-American studies at Duke University. For more on music and the 2008 Obama campaign, see Richard Daniel Blim, “The Electoral Collage: Mapping Barack Obama's Mediated Identities in the 2008 Election," in "Patchwork Nation: Collage, Music, and American Identity" (PhD diss., University of Michigan, 2013), 364-453; and Matthew F. Jordan, "Obama’s iPod: Popular Music and the Perils of Postpolitical Populism,” Popular
} 
Blender offered up commentary from Randy Newman and Girl Talk (Gregg Gillis). Both guest commentators used the candidates' tastes in music as a basis for criticizing their respective characters. Gillis inferred a narcissistic inclination led to Obama's choice of "Yes We Can," stating, "Maybe he's in love with himself and wants to hear his speeches over and over as collaged by will.i.am." Equally critical, Newman berated the Republican's choice of ABBA_listening to "Dancing Queen" too many times might raise suspicion. Surprisingly, he did not highlight the group's Swedish (read: foreign) roots. Newman also targeted the septuagenarian former POW's age by suggesting that the soft and sentimental pop of Barbra Streisand would be more fitting for his list.

\begin{tabular}{|l|l|}
\hline \multicolumn{1}{|c|}{ Barack Obama } & \multicolumn{1}{|c|}{ John McCain } \\
\hline 1. "Ready or Not" Fugees & 1. "Dancing Queen" ABBA \\
2. "What's Going On" Marvin Gaye & 2. "Blue Bayou" Roy Orbison \\
3. "I'm On Fire" Bruce Springsteen & 3. "Take a Chance on Me" ABBA \\
4. "Gimme Shelter" Rolling Stones & 4. "If We Make It Through December" Merle Haggard \\
5. "Sinnerman" Nina Simone & 5. "As Time Goes By" Dooley Wilson \\
6. "Touch the Sky" Kanye West & 6. "Good Vibrations" The Beach Boys \\
7. "You'd Be So Easy to Love" Frank Sinatra & 7. "What a Wonderful World" Louis Armstrong \\
8. "Think" Aretha Franklin & 8. "I've Got You Under My Skin" Frank Sinatra \\
9. "City of Blinding Lights" U2 & 9. "Sweet Caroline" Neil Diamond \\
10. "Yes We Can" will.i.am & 10. "Smoke Gets In Your Eyes" The Platters \\
\hline
\end{tabular}

Figure 2: John McCain and Barack Obama’s Top-10 Favorite Songs, 2008 (Blender)

Indeed, a perceived disconnect between a candidate's music tastes and the critics' perceptions of what their tastes should be engenders disparagement as well. In an interview with Walter Isaacson, McCain attempted to defend his love of ABBA, stating, "If there is anything I am lacking in, I've got to tell you, it is taste in music and art and other great things in life. I've got to say that a lot of my taste in music stopped about the time I impacted a surface-to-air missile with my own airplane and never caught up again." ${ }^{\text {} 36}$ With his measured response, McCain deflected the criticism and touted his uncultured everyman status, as well as alluded to his military service, which may be read as an attempt to reassert his masculinity. After this interview, a Blender post directly stated what Newman only implied: the two ABBA songs were "not the most, er, manly selections." ${ }^{37}$

In these instances, the list-whether it be a list of favorite artists, top-ten songs, or a rally playlistfunctions as a critical lens through which voters can make assumptions regarding a candidate's values, trustworthiness, and authenticity. Whereas fifty years ago candidates' music tastes may have seemed trivial, beginning with the rise of television the mythic, symbolic dimensions of the presidency as well as the intimacies forged through mediated technologies have shaped its cultural meanings and expectations. ${ }^{38}$ In

Communication: The International Fournal of Media and Culture 11, no. 2 (2013): 99-115.

${ }^{35}$ NPR also commented on the Blender lists, see "Music Picks from Obama, McCain," Robert Siegel and Melissa Block (hosts), All Things Considered, NPR, August 12, 2008, http://www.npr.org/templates/story/story.php?storyId=93540755.

${ }^{36}$ Peter Hamby, "McCain Rises to ABBA's Defense," CNN Political Ticker (blog), CNN, August 15, 2008, http://politicalticker.blogs.cnn.com/2008/08/15/mccain-rises-to-abbas-defense.

37 “Weird: John McCain Defends ABBA," Blender (blog), August 18, 2008, http://www.blender.com/2008/08/weird-johnmccain-defends-abba.

${ }^{38}$ Shawn J. Parry-Giles and Trevor Parry-Giles, Constructing Clinton: Hyperreality E Presidential Image-Making in Postmodern

Politics (New York: P. Lang, 2002), 1-5. 
such a political landscape, a candidate's list of favorites can be understood as a form of disclosure, a candidate's way of performing their private identity in the public sphere. Of course, this boundary remains tenuous in an environment where people's lived experiences may simultaneously unfold in cyberspace. As Web 2.0 technologies emerged, candidates developed strategies that would allow them to successfully mobilize their supporters and reach out to undecided voters in interactive virtual contexts. And for the first time, an online music strategy became as indispensible as developing a live music strategy for rallies and conventions or a canned response on music tastes for interview inquiries. ${ }^{39}$

For her 2008 presidential bid, Hillary Clinton was especially innovative in this regard: unlike her immediate predecessors, who (with the assistance of their teams) formulated their own playlists of preexisting songs, the former first lady and senator of New York launched a series of three YouTube videos where she lamented the fact that her team could not decide on a suitable campaign song and called on supporters to cast a ballot for their favorite (Video 1). Posted on her campaign website, the ballot included a list of nine preselected songs and a write-in option (Fig. 3a). ${ }^{40}$ (Voters could also click on links to hear the selections.) In the contest's introductory video, Clinton discloses her lack of musical ability by sharing footage of her "pitchy" (to drop some American Idol jargon) rendition of the national anthem at an Iowa event. ${ }^{41}$ These confessions allow Clinton to forge a bond between herself and the voters-she relies on them to create her sonic identity. Supporters active on Clinton's campaign website applauded her confession as a "brilliant move" and agreed that humor would work in her favor. ${ }^{42}$ One fan wrote: "GREAT VIDEO! That self-deprecating humor is what will bring down your negatives and bring up your favorable [sic]!" 43 Another saw the video as the candidate's subtle way of criticizing those who insisted on making news out of the trivial—a candidate's singing voice. "Your 'clip' [Clinton singing the national anthem] is exactly what you have to do to turn the tables on all the silly stuff that passes for what is important in a presidential race." ${ }^{44}$ Reality talent shows, the contest format from which Clinton draws her cues, rely on a similar strategy of confession. Disclosure plays a significant role in this television genrethe personal backstory, the behind-the-scenes footage, and the bloopers reel all work to humanize the contestant and connect performer with audience. Most fans acknowledge the contrived nature of these spectacles with their self-aggrandizement and producer-guided self-fashioning, yet they are still enchanted by them. ${ }^{45}$

\footnotetext{
${ }^{39}$ For more on web-based political engagement, see Aaron Smith, “The Internet's Role in Campaign 2008,” Pew Research Center, Washington, DC, April 15, 2009, http://pewinternet.org/Reports/2009/6--The-Internets-Role-in-Campaign2008.aspx.

40 “Campaign Song Poll," Hillary for President, May 16, 2007, http://web.archive.org/web/20070516205941/http://www.hillaryclinton.com/action/spotlight/?sc=8. There is some precedence for the song contest format in campaigns. See William Miles, Songs, Odes, Glees, and Ballads: A Bibliography of American Presidential Campaign Songsters (New York: Greenwood Press, 1990), xxxiii.

41 "Hillary Clinton Sings National Anthem," April 24, 2007, video clip, YouTube, http://www.youtube.com/watch?v=KQYIHQvhIk0. I should add that there is some disagreement over whether or not the sound of Clinton's singing voice was in some way altered.

${ }^{42}$ F4881, May 16, 2007 (8:02 p.m.), comment on Crystal Patterson, "Cast Your Vote for Hillary’s Campaign Song," blogHILLARY (blog), Hillary for President, May 16, 2007, http://web.archive.org/web/20070530183743/http://www.hillaryclinton.com/blog/view/?id=5830.

${ }^{43}$ Ryanjones, May 16, 2007 (5:52 p.m.), comment on ibid.

${ }^{44}$ Marj, May 16, 2007 (6:06 p.m.), comment on ibid.

${ }^{45}$ For excellent analysis and ethnographic work on American Idol as a cultural phenomenon, see Katherine Meizel, Idolized: Music, Media, and Identity in American Idol (Bloomington, IN: Indiana University Press, 2011).
} 
Video 1: Hillary Clinton “I Need Your Help" Video Announcement (2007)

View at: http://dx.doi.org/10.3998/mp.9460447.0009.202

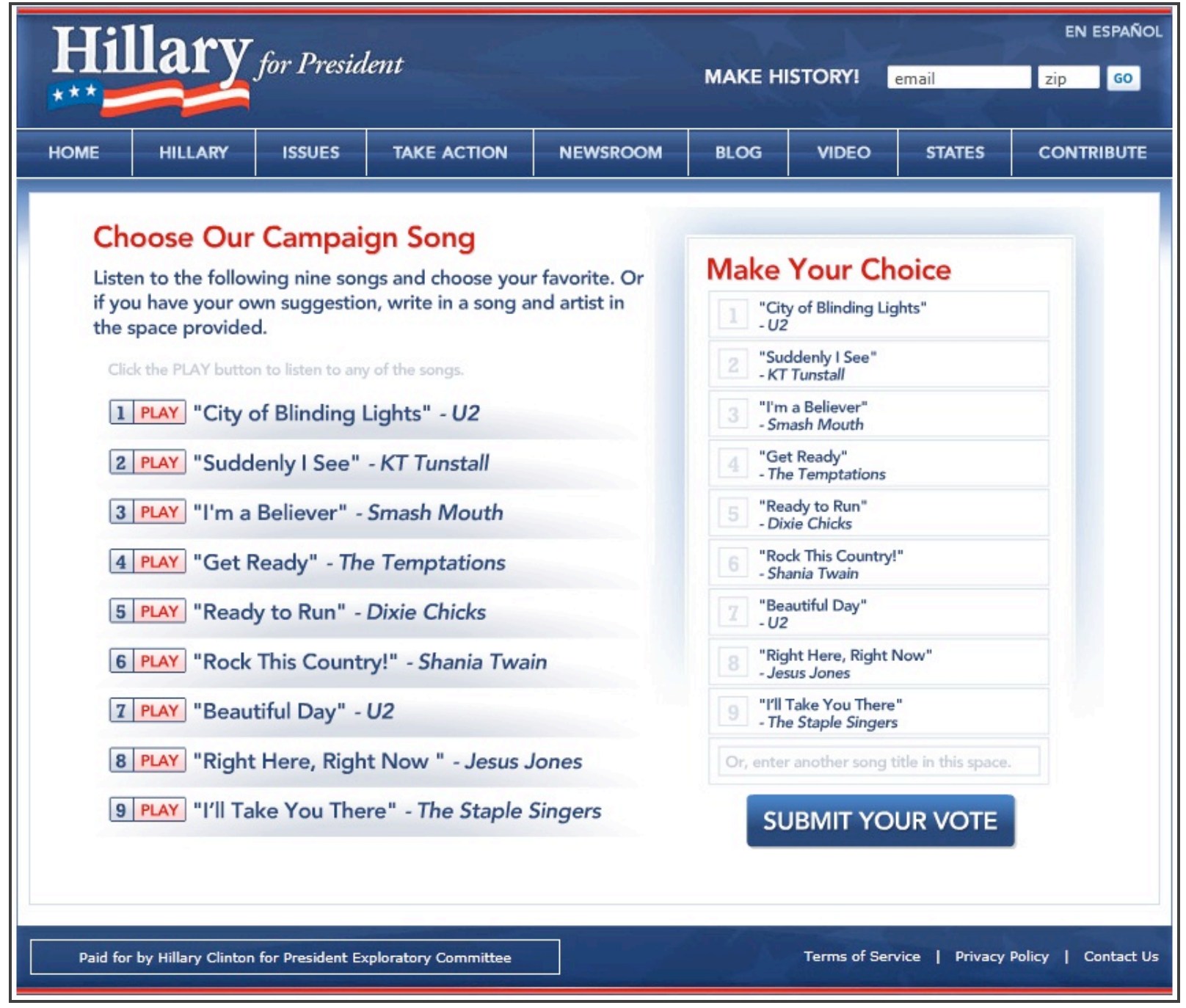

Figure 3a: Hillary Clinton “Choose Our Campaign Song” Ballot

Clinton's contest, like shows such as American Idol or America's Got Talent, relied on competition, public voting, and elimination, and, at least on the surface, created the appearance of democracy in the selection process. Her release of a second contest video (with footage of eliminated submissions) and a round-two ballot, which ranked the songs still in the running, allowed the public to witness democracy in action (Fig. 3b). ${ }^{46}$ In a sense, her strategy shares similarities with McCain's in 2008: both rely on media genres-McCain, the sports film, and Clinton, the reality show-that dramatize competition and

\footnotetext{
46 "Pick My Campaign Song: Round 2," May 24, 2012, video clip, Hillary for President, http://web.archive.org/web/20070530183843/http://www.hillaryclinton.com/action/spotlight/?sc=8. Clinton also released a third "Choose Our Campaign Song" video, a parody of The Sopranos series finale, to inform the public that a winning song was announced.
} 
domination. The contest's participatory structure helped a community of supporters for Clinton to coalesce. As they debated the appropriateness of the songs and inventoried the songs' various merits on her campaign website and YouTube channel, they assisted in the creation of her image as candidate and reaffirmed their loyalty to her.

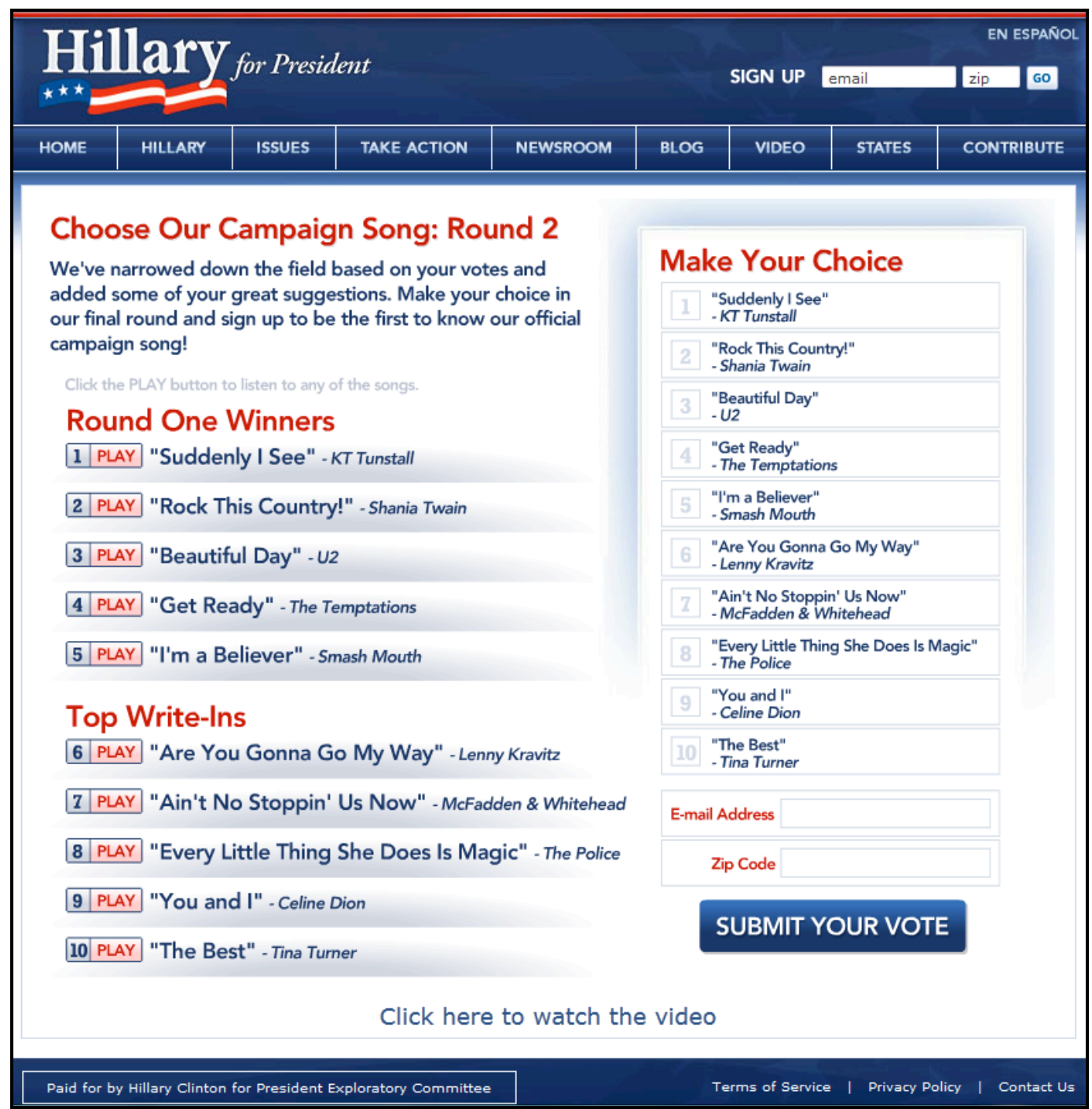

Figure 3b: Hillary Clinton "Choose Our Campaign Song: Round 2" Ballot

While the contest format modeled democratic processes, the preselected list reinforced her system of values. Most former presidential candidates primarily relied on the music of American artists; however, Clinton's list featured performers of various nationalities-U2 (Irish), KT Tunstall (Scottish), Jesus Jones (British), and Shania Twain (Canadian). ${ }^{47}$ Her first ballot included two solo female artists, one act that

${ }^{47}$ Clinton did take some flak for not having an "American enough" playlist. This is a bit surprising, as in recent years, several candidates' lists have included U2, Tunstall, and Twain. Her political advisor, Howard Wolfson, went so far as to claim that the selection of Canadian Celine Dion's song "You and I" as the contest winner doomed the Clinton campaign. See Howard Wolfson, "Campaign Playlists," New York Times, November 3, 2008, http://www.nytimes.com/2008/11/04/opinion/04wolfson.html. 
included some female singers (the Staple Singers), and a girl group (Dixie Chicks). At least in theory, Clinton reinvented the campaign soundscape with her list of suggestions and aurally established her difference from the male candidates who immediately preceded her (and who typically depended on male rock and country artists for their lists). As Clinton's playlist embraced female empowerment, selfdetermination, and strength, it concurrently thematized humanitarianism, an appreciation for nature, hope, social harmony, and caregiving. Her list, not to mention her performance in the videos and the virtual communities they mobilized, offered voters a glimpse into what they might expect from a Clinton administration and also modeled ways of being and modes of thinking that were compatible with the feminized values informing her own political and ideological orientation. ${ }^{48}$

A desire to fashion one's identity or mobilize a community may not be the primary motivators for citizens who create their own campaign-inspired lists. As my college interviewees attest, the curatorial process in and of itself can be a stimulating experience. Linking musical developments to societal modes of production, Jacques Attali describes the final network, or composition stage of cultural progress, as one "in which music could be lived as composition . . . in which it would be performed for the musician's own enjoyment, as self-communication, with no other goal than his own pleasure, as something fundamentally outside all communication, as self-transcendence, a solitary, egotistical, noncommercial act." ${ }^{\text {"9 }}$ Immersed in such a landscape, the body becomes a locus not only for production, consumption, and engagement in social relations, but also for "autonomous pleasure." ${ }^{" 50}$ In an environment where users can easily and rapidly recreate, recontextualize, and recirculate sounds (and images), the categories of producer and consumer become increasingly tenuous. Although not music composition per se, the curation of a playlist can be viewed as a composerly act. ${ }^{51}$

During campaign season, newspaper articles and blogs that address candidate music often inspire such acts. Consider, for example, the following Hillary Clinton playlist, created in response to a New York Times blog report on her campaign song contest (Fig. 4). ${ }^{52}$ For his fictional playlist, a commenter named "sd42webmaster" selects song titles that support his own take on the candidate's character. ${ }^{53}$ Instead of a celebration of hip-hop bravado, Puff Daddy's "It's All About the Benjamins" might be a critique of Clinton's blue-blooded roots, or possibly the Whitewater scandal, among other things. Through the choice of songs decrying liars, the user might be hinting at misstatements made by Clinton in the pasther claim of ducking to avoid sniper fire in Bosnia in 1996, for example. The song titles "The Great Pretender" and "Karma Chameleon" point towards a candidate with a duplicitous, deceitful nature. And not surprisingly, the gender stereotyping and accusations of gender transgression implied by titles such as "Cold as Ice," "You're So Vain," "Dude (Looks Like a Lady)," and "Evil Woman" reflect broader criticisms that detractors have leveled at Clinton since her earliest days in the spotlight.

\footnotetext{
${ }^{48}$ Adam and Derber, New Feminized Majority, 6-7; 62.

${ }^{49}$ Jacques Attali, Noise: The Political Economy of Music (Minneapolis: University of Minnesota Press, 1985$), 32$.

${ }^{50}$ Ibid.

${ }^{51}$ Henry Jenkins, Convergence Culture: Where Old and New Media Collide (New York: New York University Press, 2006$), 3-4$.

For more on the artist/audience binary, see Sinnreich, Mashed Up, chap. 5.

${ }^{52}$ Kate Phillips, “Clinton Seeks a Theme Tune," The Caucus (blog), New York Times, May 16, 2007, http://thecaucus.blogs.nytimes.com/2007/05/16/clinton-seeks-a-theme-tune/? php =true\&_type =blogs\&_r=0.

${ }^{53}$ Sd42webmaster, May 25, 2007 (5:42 p.m.), comment on Phillips, “Clinton Seeks a Theme Tune.”
} 


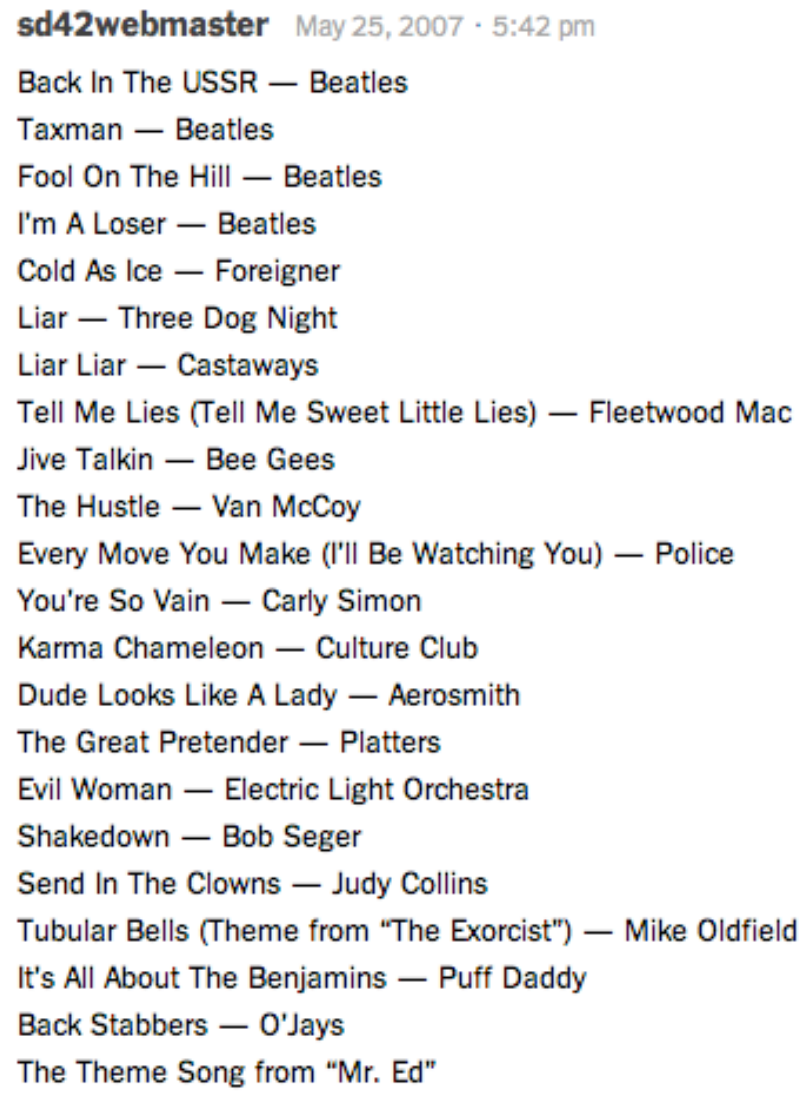

Figure 4: sd42webmaster's fictional playlist for Hillary Clinton

Fictional playlists, such as this particularly vitriolic one, afford voters an artistic platform where they can make sense of their attitude towards a particular candidate and even maintain the illusion of control over the candidate's representation. In other words, voters can deploy the rhetorical traditions associated with a genre or artist in order to construct their authority over a presidential subject purely for their own edification. To sd42webmaster, Clinton represents gender transgression, dishonesty, privilege, and callousness. We might consider not only what this list means to those who view it against the backdrop of campaign discourses but also the purpose it serves for this user. In her ethnographic work on music's function in everyday life, Tia DeNora claims music may allow listeners to create their own virtual realities where they can express themselves in a symbolically violent manner. ${ }^{54}$ While sd42webmaster may not actually listen to these selections, the act of creating the list in and of itself might be the user's way of enacting symbolic violence towards the candidate. As Belknap posits, the creation of a list "momentarily allow[s] us to order our surrounding world, verbally or symbolically putting everything into a sequence and an arrangement we desire, if only for that instant." ${ }^{55}$ The semantic openness of the list as a construct as well as pop music on the whole (as Belknap and Middleton respectively suggest) affords candidates and voters a slate on which they can compose their own identities or inscribe their own narratives if they wish.

\footnotetext{
${ }^{54}$ DeNora, Music in Everyday Life, 56.

${ }^{55}$ Belknap, List, xii.
} 


\section{“Unspeakably Cool” Lists in 2012}

In 2012 Spotify offered presidential candidates and their constituents new possibilities in the realm of list-making. The use of Spotify brought a certain level of cultural cachet to the campaigns, especially Obama's. Referencing the incumbent's Spotify playlist release, VH1 reporter Kat George claimed the embrace of such technologies gave him a "modern edge" over the other candidates and made him "unspeakably cool." 56 (Note that the altered Obama campaign logo situated in the upper-left corner of the announcement on Tumblr [Fig. 5a] takes the form of a pair of headphones, and the word "Listen" replaces the standard re-election slogan, "Forward." On a symbolic level, the visual signifier of unspeakably cool technology becomes a metonymical substitute for the Obama presidential brand. ${ }^{57}$ Shortly after the release of the "2012 Campaign Playlist," the Obama camp formally acknowledged its followers' requests for more Motown and Bruce Springsteen, initiating a music-centered dialogue that would continue throughout the campaign season (Fig. 5b). ${ }^{58}$

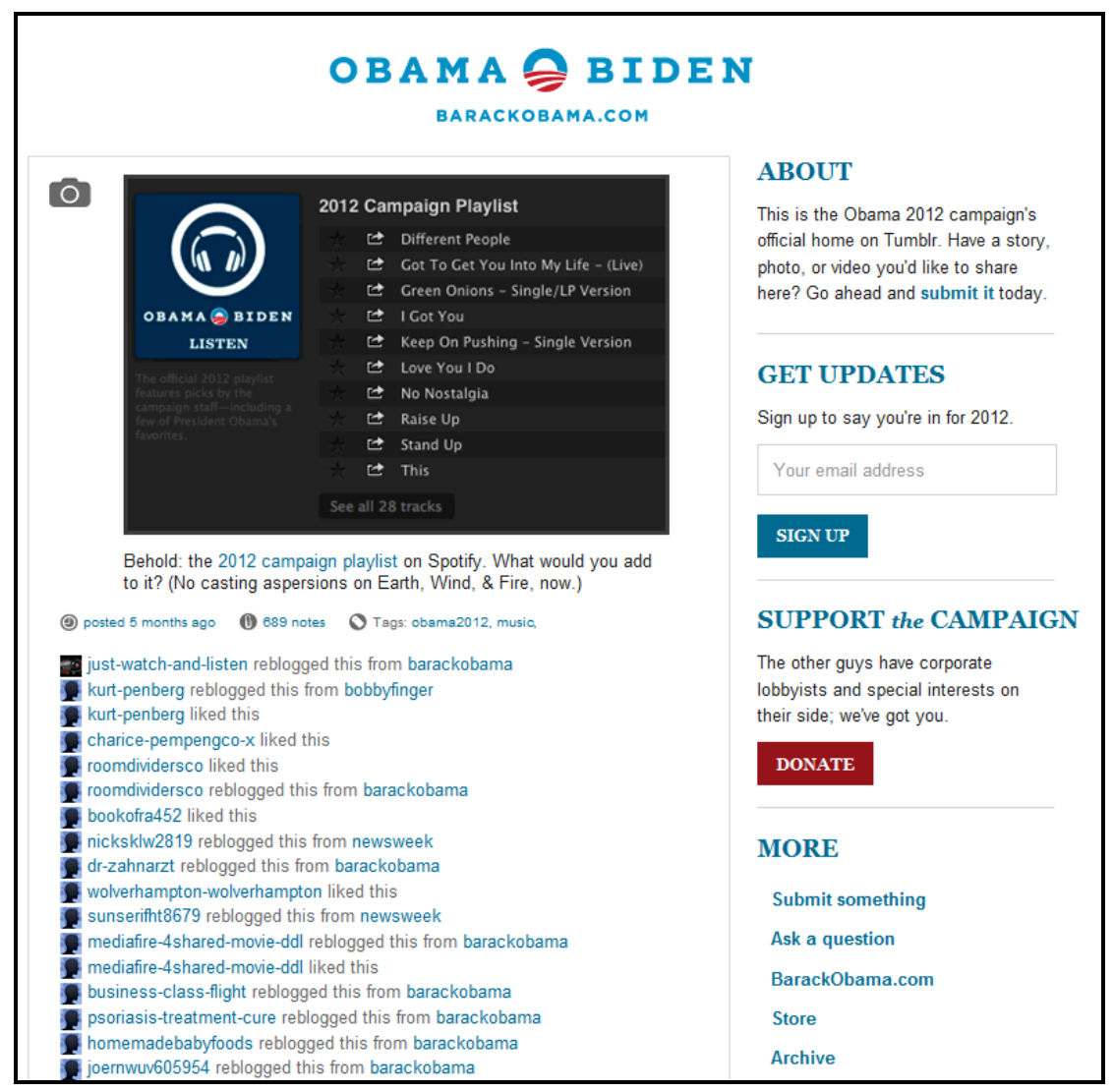

Figure 5a: Barack Obama Spotify playlist announcement on Tumblr

\footnotetext{
${ }^{56}$ George, "President Obama Releases His 28 Song Campaign Playlist."

${ }^{57}$ Barack Obama Tumblr Page, February 9, 2012, http://barackobama.tumblr.com/post/17319836576/behold-the-2012campaign-playlist-on-spotify. For more on the "O" logo, see Patrick B. Oray, "Myth, Symbol, and the Branding of an American Presidency," in The Iconic Obama, 2007-2009: Essays on Media Representations of the Candidate and New President, ed. Nicholas A. Yanes and Derrais Carter (Jefferson, NC: McFarland, 2012), 28-42, esp. 36-41.

${ }^{58}$ Barack Obama Tumblr page, February 9, 2012, http://barackobama.tumblr.com/post/17329917914/tumblrs-campaignplaylist-suggestions-so-far.
} 


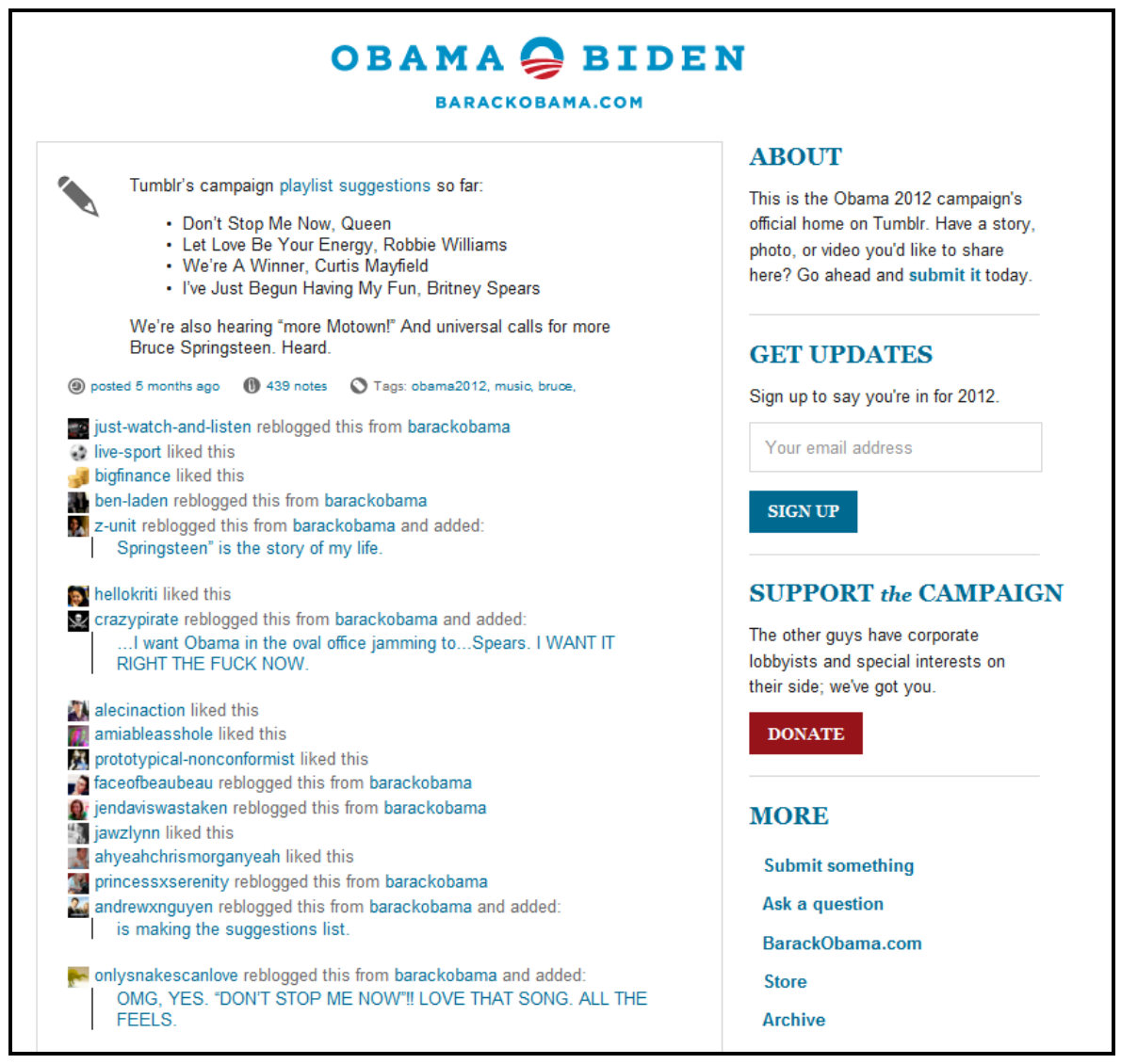

Figure 5b: Tumblr community responses to Barack Obama’s Spotify playlist

In choosing Aretha Franklin, Booker T. \& the M.G.'s, the Impressions, and Al Green, the candidate stayed true to the old-school-guy persona he cultivated during his previous campaign-in 2008, U2, Bruce Springsteen, Natasha Bedingfield, India.Arie, and Ben Harper diversified the list, but R\&B from the '60s and '70s dominated the soundscape overall: Stevie Wonder's "Signed, Sealed, Delivered I'm Yours" (1970), the O'Jays' “Give the People What They Want” (1975), Aretha Franklin's “Think” (1968), Jackie Wilson's "(Your Love Keeps Lifting Me) Higher and Higher" (1967), and Curtis Mayfield's "Move on Up” (1970) were in heavy rotation. ${ }^{59}$ While retro R\&B still held its sway, and Springsteen and U2 appeared on the list once again, the overall composition of Obama's 2012 Spotify list differed from the rally lists he featured during his previous stint on the presidential campaign trail. Obama rounded out his playlist with a handful of indie groups in 2012: AgesandAges, Noah and the Whale, Florence + the Machine, and Arcade Fire (Fig. 6a). ${ }^{60}$ The 2012 playlist certainly can be described as more "international" than his 2008 list: Noah and the Whale, Florence + the Machine, and Electric Light Orchestra come from the UK, and Arcade Fire, the 2011 Grammy Award winner for Album of the Year, hails from Québec. Country music also played a more prominent role: Obama included Montgomery Gentry, Zac Brown Band, Dierks Bentley, and Darius Rucker. Most notably, contemporary tunes outnumbered older ones-eighteen of the twenty-

\footnotetext{
${ }^{59}$ Dave Beard, “'Celebration' and 'There's Hope' on Obama's Setlist,” Boston.com, January 5, 2008, http://www.boston.com/news/politics/politicalintelligence/2008/01/celebration and.html. Slate (and other websites) posted lists of the songs Obama used on the campaign trail. See Christopher Beam, "Barack Obama's iTunes Playlist," Trailhead (blog), Slate, January 26, 2008, http://www.slate.com/blogs/trailhead/2008/01/26/barack_obama_s itunes_playlist.html. ${ }^{60}$ User information has been shaded in the images of the Spotify playlists in order to protect privacy.
} 
eight selections on the playlist were released in 2002 or later. (Compare this to the January 2008 rally playlist in Figure 6b. Only three of the twenty-one songs included were released in the twenty-first century).

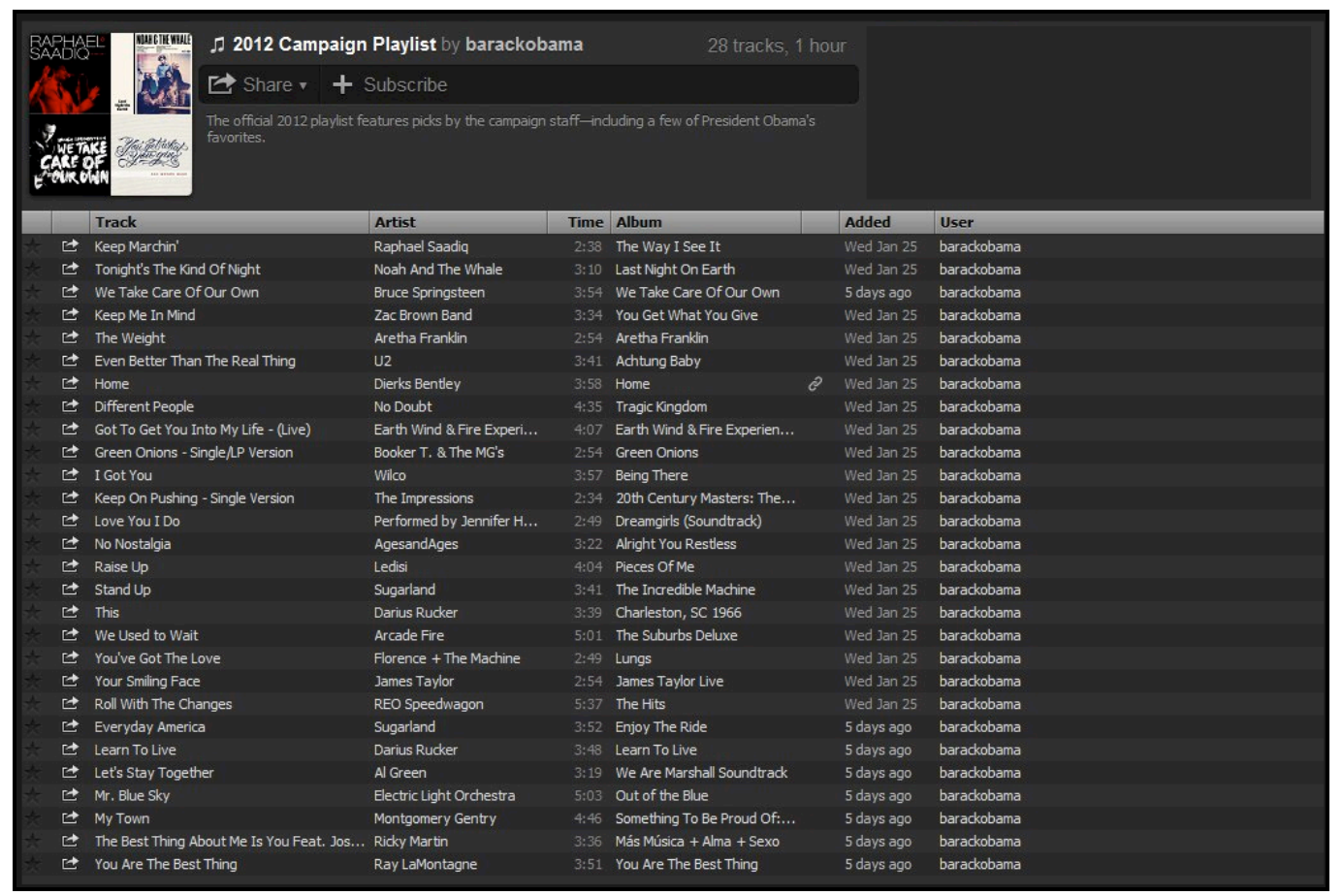

Figure 6a: Barack Obama’s “2012 Campaign Playlist” (Spotify)

1. “Ain't No Mountain High Enough" (1967) Marvin Gaye and Tammi Terrell

2. "St. Elmo's Fire (Man in Motion)" (1985) John Parr

3. "The Best" (1989) Tina Turner

4. "Takin' It To The Streets" (1976) The Doobie Brothers

5. "Shining Star" (1975) Earth, Wind \& Fire

6. "Give The People What They Want" (1975) O'Jays

7. "Hold On, I'm Comin"” (1966) Sam \& Dave

8. "Celebration" (1980) Kool \& the Gang

9. "Unwritten" (2004) Natasha Bedingfield

10. "Shout" (1959) The Isley Brothers

11. "Get Ready" (1966) The Temptations

12. "There's Hope" (2006) India.Arie

13. “Ain't No Stoppin' Us Now" (1979) McFadden \& Whitehead

14. "I'll Take You There" (1972) The Staple Singers

15. "Still The One" (1976) Orleans

16. "Everyday People" (1968) Sly and the Family Stone

17. "Long Train Runnin"” (1973) The Doobie Brothers

18. "Sir Duke" (1976) Stevie Wonder

19. "Centerfield" (1985) John Fogerty

20. "City of Blinding Lights" (2004) U2 (for Obama entrance)

21. "Signed, Sealed, Delivered I'm Yours" (1970) Stevie Wonder

Figure 6b: Playlist for a January 2008 Barack Obama rally 
Many journalists and online commenters shared their views on the "new" sound of Obama's 2012 campaign. Margaret Talev and Kate Andersen, for example, noted the shift in thematic contents:

In 2008, Obama was promising to "change the world," and the music he used was an upbeat mix that included soul and Motown hits such as Curtis Mayfield's "Move on Up" and Stevie Wonder's "Signed, Sealed, Delivered I'm Yours." With the unemployment rate hovering at more than 8 percent and the partisan divide in Washington hardening, the new list, being released by the campaign today, incorporates a mix of artists, ages and genres with songs that touch upon themes such as will, redemption and comeback. ${ }^{61}$

Choosing a more "scientific" route, Jordan Wolf conducted quantitative analysis on the lyrics of the 2012 songs: "The component words of the stereotypical feel-good song-'love,' 'life' and 'good'—show up plenty, but they are dwarfed by the appearances of 'keep." 62 The emphasis on "keep," Wolf argues, points towards the importance of "striving toward a goal in the face of adversity." 63 The Washington Post's Chris Richards called the list "a collection of songs designed to make the recipient fall in love with the sender." But not everyone fell in love. Some accused Obama of trying too hard. One Huffington Post commenter wrote, "That's the kind of playlist that would make the 'striving-for-diversity' phony photos on most college's [sic] publicity materials very proud." 65 Another expressed disappointment over hip-hop's exclusion, claiming the staff forgot Jay $\mathrm{Z}$ and Common. ${ }^{66}$

The omission of hip-hop is notable, considering the fact that numerous hip-hop moguls and artists enthusiastically endorsed the candidate in $2008 .{ }^{67}$ The endorsements also came in a musical form: as

\footnotetext{
${ }^{61}$ Margaret Talev and Kate Andersen Brower, “Obama's Changing His Tune for 2012 Campaign's Mood Music,” Bloomberg Businessweek, February 14, 2012, http://www.businessweek.com/news/2012-02-14/obama-s-changing-his-tune-for-2012campaign-s-mood-music.html.

${ }^{62}$ Jordan Wolf, “The Soundtrack to Barack Obama's 2012 Reelection Campaign,” Mic.com, February 9, 2012, http://mic.com/articles/4053/the-soundtrack-to-barack-obama-s-2012-reelection-campaign.

${ }^{63}$ Ibid.

${ }^{64}$ Chris Richards, “The Mixed Bag of Obama's Campaign Song Playlist,” Washington Post, February 9, 2012, http://www.washingtonpost.com/lifestyle/style/the-mixed-bag-of-obamas-campaign-songplaylist/2012/02/09/gIQAVCqX2Q story.html. Cited in "Obama's Spotify Playlist: 7 Things It Says About His Campaign," The Week, February 10, 2012, http://theweek.com/article/index/224286/obamas-spotify-playlist-7-things-it-says-about-hiscampaign. In the Post article, Richards refers to email correspondence revealing that the candidate did not choose the songs himself-staff and volunteers made the selections. The list description on Spotify hints towards this: "The official 2012 playlist features picks by the campaign staff_including a few of President Obama's favorites."

${ }^{65}$ iAREamerica, February 10, 2012 (12:32 p.m.), comment on Jason Gilbert, "Barack Obama's Spotify Playlist Reveals Love For No Doubt, Wilco," Huffington Post, February 9, 2012, http://www.huffingtonpost.com/2012/02/09/barack-obama-spotifyplaylist n 1266372.html.

${ }^{66}$ Righteousindignation, February 10, 2012 (1:19 a.m.), comment on ibid.

${ }^{67}$ Several scholars have addressed hip-hop and Obama's 2008 candidacy. See Travis L. Gosa, "Not Another Remix: How Obama Became the First Hip-Hop President," Fournal of Popular Music Studies 22, no. 4 (2010): 389-415; and “The Audacity of Dope': Rap Music, Race, and the Obama Presidency," in The Iconic Obama, 2007-2009: Essays on Media Representations of the Candidate and New President, ed. Nicholas A. Yanes and Derrais Carter (Jefferson, NC: McFarland, 2012), 85-96; Erik Nielson, “My President is Black, My Lambo's Blue': The Obamafication of Rap?” fournal of Popular Music Studies 21, no. 4 (2009): 344-63; Murray Forman, “Conscious Hip-Hop, Change, and the Obama Era," American Studies Fournal 54 (2010), http://asjournal.zusas.uni-halle.de/179.html; Lester K. Spence, "Obama and the Future of Hip-hop Politics," in Stare in the Darkness: The Limits of Hip-hop and Black Politics (Minneapolis: University of Minnesota Press, 2011), 157-76; Michael P. Jeffries, "Obama as Hip-Hop Icon," epilogue to Thug Life: Race, Gender, and the Meaning of Hip-Hop (Chicago: University of Chicago Press, 2011), 199-206; H. Samy Alim and Geneva Smitherman, “'My President's Black, My Lambo's Blue’: Hip Hop, Race, and the Culture Wars," in Articulate While Black: Barack Obama, Language, and Race in the U.S. (Oxford: Oxford University Press, 2012), 130-66; Shaun Ossei-Owusu, "Barack Obama's Anomalous Relationship with the Hip-Hop Community," in The Obama Phenomenon: Toward a Multiracial Democracy, ed. Charles P. Henry, Robert L. Allen, and Robert Chrisman (Urbana: University of Illinois Press, 2011), 218-35; Sanford K. Richmond, "Paint The White House Black!! A Critical Discourse Analysis Look at Hip Hop's Social, Cultural, and Political Influence on the Presidency of Barack Obama." Western Fournal of Black Studies 37, no. 4 (Winter 2013): 249-57; Mark Anthony Neal, "Obama Hip-Hop: From Mixtapes to Mainstream," interview with Liane Hansen, Weekend Edition Sunday, NPR, November 7, 2008,
} 
Travis L. Gosa has shown, a large number of newly composed, Obama-themed hip-hop tracks and mixtapes circulated on sites such as MySpace and DatPiff. ${ }^{68}$ In an article addressing the reasons why hiphop "fell out of love" with Obama, Tricia Rose provided the following explanation:

Quite obviously, black America is in terrible crisis... . The racial and class dimensions of this crisis have simply been largely sidestepped by the Obama presidency and muted by black leadership, which seems largely frozen by the effect of not wanting to undermine the first black president. ${ }^{69}$

Obama's alleged inability to rectify issues plaguing black communities might partially explain hip-hop's lukewarm stance and the musical barbs its artists directed towards the president in the years following his historic ascendancy. Trends' mixtape The Inauguration (2009) and Lupe Fiasco's single, "Words I Never Said" (2011), featured caustic critiques of the new president, and 2008 Obama-supporter Sean Combs took to the Internet in 2011 to demand the president directly address the plight of the black constituents that helped put him in the oval office. ${ }^{70}$ But as Erik Nielson suggests, the chilly reception went both ways. In May 2011 the Obamas invited the rapper Common (Lonnie Rashid Lynn Jr.) to perform at the White House, a gesture that ruffled the feathers of several prominent Republicans who objected to the administration showcasing a so-called "thug." Fear of even more conservative backlash, and a need to attract swing voters may have encouraged Obama to downplay his connections with hip-hop during the 2012 campaign. $^{71}$

Eager to establish his own coolness quotient, Romney released a Spotify playlist, titled "On the Road," a month after Obama's list made the rounds. Like his opponent, he featured some country music. With songs such as Keith Urban's "Somebody Like You” and Toby Keith's "As Good As I Once Was," Romney projected confidence and the Southern ethos of masculinity. ${ }^{72}$ Rounding out his playlist with Frankie Valli and the Four Seasons, the Kingston Trio, the Beach Boys, and Roy Orbison, the Republican candidate exuded a somewhat retro vibe, just as Obama did in 2008 (Fig. 7a). Although the former governor managed to locate "binders full of women" for his Massachusetts cabinet, he could only find one female artist for his Spotify playlist: Carrie Underwood. The list he established for rallies did include more women—country artists Taylor Swift and Miranda Lambert (Fig. 7b). ${ }^{73}$ Some talking heads criticized the

http://www.npr.org/templates/story/story.php?storyId=96748462. Two forthcoming volumes will also address this topic: Travis L. Gosa and Erik Nielson, eds., The Hip Hop E Obama Reader (New York: Oxford University Press, 2015); and Bakari Kitwana, Hip-Hop Activism in the Obama Era (Chicago: Third World Press, 2015).

${ }^{68}$ Gosa, "Not Another Remix," 389-415.

${ }^{69}$ Quoted in Erik Nielson, "How Hip-Hop Fell Out of Love with Obama," Guardian, August 23, 2012, http://www.theguardian.com/music/2012/aug/23/why-hip-hop-deserting-obama.

${ }^{70}$ Gosa, “Audacity of Dope," 92-93. Also see CJ Rutter, "P Diddy: 'Obama Owes Us!' Hip Hop Mogul Wants The President To Stand Up ...” TaleTela, February 1, 2011, http://www.taletela.com/news/4770/p-diddy-'obama-owes-us'.

${ }^{71}$ Nielson, "How Hip-Hop Fell Out of Love.” The relationship with Jay Z did continue, however. For example, Obama created a video message for Jay Z's first Made in America festival in September of 2012. In it he stated, "To me, the idea of America is that no matter who you are, what you look like or where you come from, you can make it if you try. Jay $Z$ did it. He didn't come from power or privilege. [. . . He got ahead because he worked hard, learned from his mistakes and just plain refused to quit. That's what 'made in America' means." At a 40/40 Club fundraiser later in the same month, Obama saluted organizers Jay $\mathrm{Z}$ and Beyoncé, and claimed he and the mogul had several things in common: "Jay $\mathrm{Z}$ now knows, you know, what my life is like. We both have daughters. And our wives are more popular than we are ... So we've got a little bond there. It's hard, but it's OK." See Gil Kaufman, "Jay Z and President Obama: A Bromance History,” MTV.com, September 19, 2012, http://www.mtv.com/news/1694108/jay-Z-obama-bromance.

${ }^{72}$ David R. Dewberry and Jonathan H. Millen, "Music as Rhetoric: Music in the 2012 Presidential Campaign," in Studies of Communication in the 2012 Presidential Campaign, ed. Robert E. Denton Jr. (Lanham, MD: Lexington, 2014 ), 187.

${ }^{73}$ James Hohmann, “Mitt Romney’s Campaign Rally Playlist," CLICK (blog), Politico, October 30, 2012, http://www.politico.com/blogs/click/2012/10/mitt-romneys-campaign-rally-play-list-147738.html. In the October 16,2012 


\begin{tabular}{|c|c|c|c|c|c|c|}
\hline & Track & Artist & Time & Album & Added & User \\
\hline$\leftarrow$ & I Am A Man Of Constant Sorrow & The Soggy Bottom Boys & $4: 17$ & O Brother, Where Art Th. & 2 days ago & mittromney \\
\hline$\leftarrow$ & Read My Mind & The Killers & $4: 07$ & Sam's Town & 2 days ago & mittromney \\
\hline$\Leftrightarrow$ & December, 1963 [Oh What A Night!] & Frankie Valli \& The Fo. & $3: 21$ & December, 1963 [Oh Wh. & 2 days ago & mittromney \\
\hline$\Leftrightarrow$ & Ring Of Fire & Johnny Cash & $2: 51$ & Ring Of Fire & 2 days ago & mittromney \\
\hline 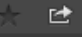 & Somebody Told Me & The Killers & $3: 17$ & Hot Fuss & 2 days ago & mittromney \\
\hline$\leftarrow$ & The M T A (The Boston Subway Song) & The Kingston Trio & $2: 54$ & Kingston Trio & 2 days ago & mittromney \\
\hline$\leftarrow$ & Good Vibrations & The Beach Boys & $3: 38$ & Good Vibrations 40th A. & 2 days ago & mittromney \\
\hline 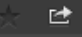 & Desperado - (Live) & Clint Black & $4: 04$ & Greatest Hits & 2 days ago & mittromney \\
\hline$\leftarrow$ & Crying & Roy Orbison & $2: 46$ & Crying & 2 days ago & mittromney \\
\hline$\bullet$ & Only You - Long Version & Commodores & $5: 02$ & Motown Legends: The $\mathrm{C}$. & 2 days ago & mittromney \\
\hline$\leftarrow$ & Runaway & Del Shannon & $2: 27$ & $\# 1$ Hits of The 60 's & 2 days ago & mittromney \\
\hline 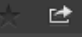 & It's Your Love & Tim McGraw & $3: 46$ & Number One Hits & 2 days ago & mittromney \\
\hline 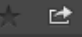 & As Good As I Once Was & Toby Keith & $3: 48$ & Honkytonk University & 2 days ago & mittromney \\
\hline$\leftarrow$ & Born Free & Kid Rock & $4: 25$ & Born Free & 2 days ago & mittromney \\
\hline$\Leftrightarrow$ & Over The Rainbow & Willie Nelson & $3: 36$ & Somewhere Over The Ra. & 2 days ago & mittromney \\
\hline$\hookleftarrow$ & Stardust & Nat King Cole & $3: 14$ & The Nat King Cole Story & 2 days ago & mittromney \\
\hline 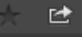 & In Dreams & Roy Orbison & $2: 49$ & Roy Orbison - 16 Bigges. & 2 days ago & mittromney \\
\hline$\leftarrow$ & Somebody Like You (Album Version) & Keith Urban & $5: 23$ & Greatest Hits - 18 Kids & 2 days ago & mittromney \\
\hline 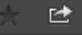 & All-American Girl & Carrie Underwood & $3: 32$ & Carnival Ride & 2 days ago & mittromney \\
\hline
\end{tabular}

Figure 7a: "On the Road," a playlist by Mitt Romney (Spotify)

\begin{tabular}{|c|}
\hline 1. "Only in America" Brooks \& Dunn \\
2. "Hollywood Nights" Bob Seger \\
3. "Dancing in the Street" Martha and the Vandellas \\
4. "Still the Same" Bob Seger \\
5. "Detroit Rock City" Kiss \\
6. "Here I Go Again" Whitesnake \\
7. "Shout it Out Loud" Kiss \\
8. "Dirt Road Anthem" Jason Aldean \\
9. "Lover, Lover" Jerrod Niemann \\
10. "Honey Bee" Blake Shelton \\
11. "Knee Deep" Zac Brown Band \\
12. "Mine" Taylor Swift \\
13. "Ours" Taylor Swift \\
15. "Over You" Miranda Lambert \\
16. "Banjo" Rascal Flatts \\
17. "New Sensation" INXS \\
18. "You Gonna Fly" Keith Urban \\
19. "It's America" Rodney Atkins \\
20. "My Kinda Party" Jason Aldean \\
21. "Country Girl (Shake It For Me)" Luke Bryan \\
22. "Country Must Be Country Wide" Brantley Gilbert \\
23. "I Heard It Through the Grapevine" Marvin Gaye
\end{tabular}

Figure 7b: Playlist for an October 2012 Mitt Romney rally

presidential debate, Mitt Romney used this infamous phrase in response to a question regarding gender-based pay inequality. To give an example of his own efforts to bring women into the workplace, he referred to his cabinet assembly process when he was governor of Massachusetts. He stated, "I went to a number of women's groups and said, 'Can you help us find folks,' and they brought us whole binders full of women." The awkward turn of phrase quickly led to numerous memes, a Facebook page, and a Twitter hashtag. See Suzi Parker, "Mitt Romney's 'Binders Full of Women," She The People (blog), Washington Post, October 17, 2012, http://www.washingtonpost.com/blogs/she-the-people/wp/2012/10/17/mitt-romneys-binders-full-ofwomen. 
tone of Romney's Spotify list: Slate's David Weigel called it "surprisingly forlorn," 74 and one blogger (who is also an ethnomusicologist) described it as "a cavalcade of victimhood, weakness, pain, and dependence." 75 The exclusion of women vexed some, and others questioned Romney's tech-savviness, a common charge leveled at GOP candidates. One user exclaimed, "Wow. Romney's butler has put together a great Spotify list! Romney's probably not an avid user, but he's good friends with the guy who owns the company." ${ }^{76}$ Voters (and music artists) frequently criticize presidential hopefuls for choosing songs with lyrics that seem misaligned with their image, and they map this deception onto a broader critique of the candidate's perceived trustworthiness.

Whereas Obama presented his Spotify list as a campaign playlist, or public music, Romney described his as a list created for private use. He tweeted, "Spending a lot of time on the road means you have to carry good music - here are some of my favorites." 77 His declaration, like Hillary Clinton's confession of tone deafness in 2007, was an act of disclosure intended to establish intimacy with supporters. The thematic content of his list supports this supposition- "On the Road" features introspective, first-person narratives exploring love, loss, and personal transformation. Is Romney trying to minimize the public's perception of him as an arrogant, out of touch aristocrat? ${ }^{78}$ With bluegrass-styled songs, such as "I Am a Man of Constant Sorrow," it might seem so, but unfortunately, commenters saw little commonality between Romney and the disempowered, pathetic protagonists of his favorite songs. One Huffington Post commenter claimed,

Anything as personal as a playlist (even Obama's) is as spontaneously put together as one of LeAnn Rimes' pictures cavorting on the beach in a bikini. This is all PR . . . that's all it is. No one is going to post a playlist with the stuff they really listen to for the world to see. I would hate for my dorky music (peppered here and there with some cool stuff) to fall into the hands of people who will judge me based on it. ${ }^{79}$

This commenter is not alone in her fear of being outed as a consumer of "dorky music." A list curator's anxiety over the public's surveillance may impact how they disclose their "self" through music. Pundits and online commenters obliquely acknowledge the performative dimension of these curatorial acts, but still consider playlists a divining rod that can lead to insight regarding a candidate. And perhaps perception is all that matters. Psychologists Peter J. Rentfrow and Samuel D. Gosling establish correlations between music tastes and personality types, and indeed their survey participants believe that such preferences can provide insight into their own personalities and those of others. ${ }^{80}$ As Jean Baudrillard

\footnotetext{
${ }^{74}$ David Weigel, “Mitt Romney’s Spotify Playlist,” Weigel (blog), Slate, March 9, 2012, http://www.slate.com/blogs/weigel/2012/03/09/mitt_romney_s spotify_playlist.html.

${ }_{75}$ HeartsAndEars [Jason Lee Oaks], September 19, 2012 (9:46 p.m.), comment on Ariel Edwards-Levy, "Mitt Romney's Spotify Playlist," Huffington Post, March 9, 2012, http://www.huffingtonpost.com/2012/03/09/mitt-romneys-spotifyplay n 1335839.html. Also see Oakes's informative blog, Winning Hearts \& Ears, which provides commentary on music and political campaigns. For example, “Mitt’s Mix,” Winning Hearts E Ears (blog), September 19, 2012, http://heartsandears.wordpress.com/2012/09/19/mitts-mix.

${ }_{76}$ Pthesmith, March 12, 2012 (3:13 p.m.), comment on Edwards-Levy, "Mitt Romney’s Spotify Playlist.”

${ }^{77}$ Mitt Romney Twitter page, March 9, 2012, https://twitter.com/MittRomney/statuses/178230960003878913.

${ }^{78}$ For more on the public's perception of Romney's image, see “Romney in a Word: 'Honest,' 'Businessman,' 'Rich,'” Pew Research Center for the People \& the Press, August 29, 2012, http://www.people-press.org/2012/08/29/romney-in-a-wordhonest-businessman-rich.

${ }^{79}$ MBGarcia, March 12, 2012 (4:36 p.m.), comment on Edwards-Levy, “Mitt Romney's Spotify Playlist.”

${ }^{80}$ Peter J. Rentfrow and Samuel D. Gosling, “The Do Re Mi's of Everyday Life: The Structure and Personality Correlates of Music Preferences," Fournal of Personality and Social Psychology 84, no. 6 (June 2003): 1236-256. Also see Amy Voida, Rebecca E. Grinter, Nicolas Ducheneaut, W. Keith Edwards, and Mark W. Newman, "Listening In: Practices Surrounding iTunes Music Sharing," in CHI '05 Proceedings of the SIGCHI Conference on Human Factors in Computing Systems (New York, NY:
} 
posits, "the objects in our lives, as distinct from the way we make use of them at a given moment, represent something much more, something profoundly related to subjectivity." $\$ 1$

Like Hillary Clinton in the 2008 Democratic primary, Obama offered a song recommendation form on his website, seeking the public's assistance in the creation of a "winning soundtrack" for his 2012 rallies (Fig. 8a): "As we head into rally season, what music gets you fired up? Submit your favorite tracks below, and you could see them on the Obama 2012 Supporter Picks playlist on Spotify." " Contributors to the "Supporter Picks" list (Fig. 8c) took their cues from Obama's previous playlists. As already noted, 2008 rallies featured Mayfield's "Move on Up" and Franklin's "Think," Springsteen favorites made an appearance in both election years, and the "2012 Campaign Playlist" on Spotify included selections by Franklin and Arcade Fire. Obama followers likely remembered Beyoncé's performance of Etta James's classic cover "At Last" at the 2008 Neighborhood Inaugural Ball. With these songs, a nonlinear narrative of sorts, or perhaps an inventory of the campaign soundscape emerges. With the "Supporter Picks" list, we have the nostalgic sounds of Obama's first presidential campaign (Mayfield and Franklin), his first introduction as president (James), and the contemporary sound of his 2012 campaign (Arcade Fire). The

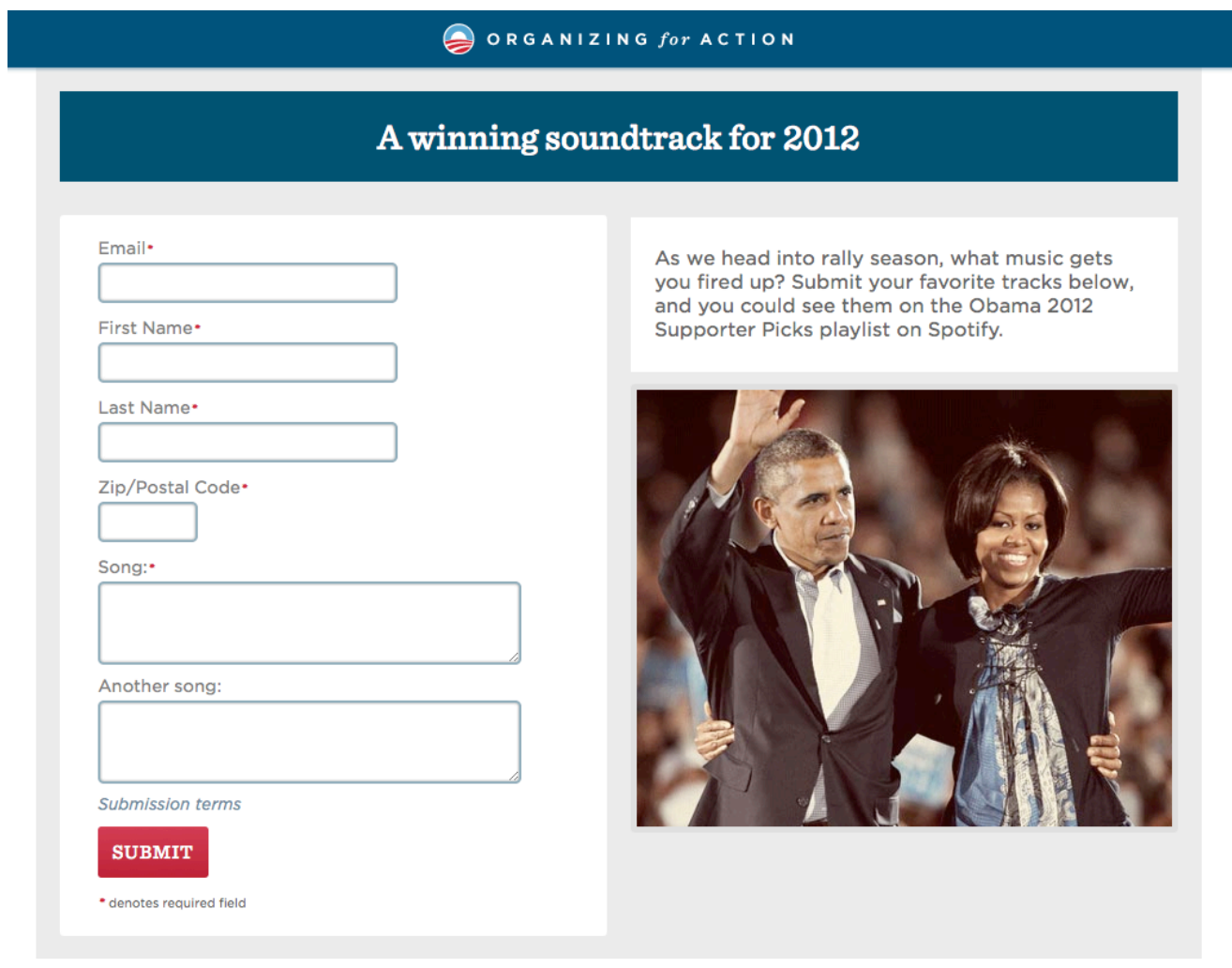

Figure 8a: Barack Obama online song recommendation form

Association for Computing Machinery, 2005), 191-200; and Gilpin, “Working in the Twittersphere," 250.

${ }^{81}$ Jean Baudrillard, "The System of Collecting," in The Cultures of Collecting, ed. John Elsner and Roger Cardinal (Cambridge, MA: Harvard University Press, 1994), 7.

82 “A Winning Soundtrack for 2012,” Barack Obama’s website, accessed June 1, 2015, my.barackobama.com/page/s/2012soundtrack. Also see Jason Gilbert, “Obama's Spotify Playlist for 2012 Campaign: President Asks Voters To Soundtrack The Election," Huffington Post, May 4, 2012, http://www.huffingtonpost.com/2012/05/04/obama-spotify-2012 n $1478026 . h$ tml. 


\section{Barack Obama $\bullet$ \\ @BarackObama}

\section{Follow}

\section{Afternoon soundtrack: the \#Obama2012 supporter-picks playlist. OFA.BO/bAZ2Rw \\ น Reply $\mathbf{\imath} \mathbf{7}$ Retweet $\downarrow$ Favorite $\bullet \bullet$ More \\ t Tumblr}

Last week, we asked you what your favorite...

Last week, we asked you what your favorite fired-up songs are. Here's what you said-now in a supporter-picks Spotify playlist. Journey haters to the right.

View on web

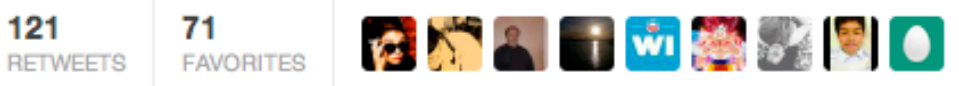

3:28 PM - 7 May $12 \quad$ Flag media

Figure 8b: Barack Obama "Supporter Picks" playlist announcement on Twitter

Fil What's New

2. People

$\square$ Inbox

르 Play Queue

[ Devices

ลี App Finder

${ }_{23}$ Top Lists

(o) Radio

COLLECTION

1) Library

B Local Files

$\star$ Starred

+ New Playlist

J 2012 Campaign Playlist

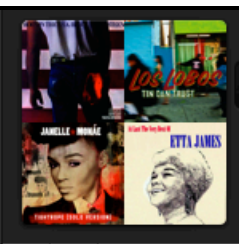

J. Supporter Picks by barackobama 17 tracks, 1 hour

$\longleftrightarrow$ Share v ((o)) Start Playlist Radio + Subscribe

Tracks submitted by supporters across the country-help us create a

winning soundtrack between now and November by submitting your

favorites.

\begin{tabular}{|c|c|c|c|c|c|c|c|}
\hline & Track & Artist & Time & Album & & Added & User \\
\hline 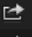 & Born In The U.S.A. & Bruce Springsteen & $4: 38$ & Born In The U.S.A. & B & Fri Mar 30 & barackobama \\
\hline$\bullet$ & On Main Street & Los Lobos & 3:17 & Tin Can Trust & & Fri Mar 30 & barackobama \\
\hline 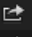 & Tightrope - The Solo Version & Janelle Monáe & 4:25 & Tightrope & & Fri Mar 30 & barackobama \\
\hline$\bullet$ & At Last & Etta James & 3:02 & At Last The Very Best of & & Fri Mar 30 & barackobama \\
\hline$\bullet$ & Energy & The Apples In Stereo & 3:31 & New Magnetic Wonder & & Fri Mar 30 & barackobama \\
\hline$\bullet$ & Wake Up Everybody feat. Common \& & John Legend \& The Ro. & $4: 25$ & Wake Up! & & Fri Mar 30 & barackobama \\
\hline$\Leftrightarrow$ & Move On Up & Curtis Mayfield & $3: 41$ & Future Shock & B & Fri Mar 30 & barackobama \\
\hline 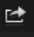 & I Won't Back Down & Tom Petty & 2:55 & Anthology: Through The. & & Fri May 4 & barackobama \\
\hline 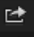 & La Copa De La Vida (La Cancion Oficia & Ricky Martin & $4: 37$ & Ricky Martin & & Fri May 4 & barackobama \\
\hline 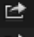 & Suddenly I See & KT Tunstall & $3: 21$ & Eye To The Telescope & B & Fri May 4 & barackobama \\
\hline$\hookleftarrow$ & Respect & Aretha Franklin & $2: 23$ & Rhino Hi-Five: Various A & & Fri May 4 & barackobama \\
\hline$\hookleftarrow$ & Don't Stop Believin' & Journey & 4:09 & The Essential Journey & & Fri May 4 & barackobama \\
\hline 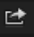 & That's Good & Devo & $3: 25$ & Oh No! It's Devo & & Fri May 4 & barackobama \\
\hline$\bullet$ & SING & My Chemical Romance & $4: 30$ & Danger Days: The True. & & Fri May 4 & barackobama \\
\hline 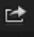 & Block After Block & Matt \& Kim & 2:56 & Sidewalks & & Fri May 4 & barackobama \\
\hline$\bullet$ & Proud Mary & Tina Turner & $5: 26$ & Tina! & & Fri May 4 & barackobama \\
\hline$\bullet$ & Wake Up & Arcade Fire & $5: 35$ & Funeral & & Fri May 4 & barackobama \\
\hline
\end{tabular}

Figure 8c: Barack Obama "Supporter Picks" playlist (Spotify) 
recommendation form, Spotify format, and integration with social media allowed voters to act as both producers and consumers of Obama's list. These participatory acts established solidarity between the candidate and his community of supporters, and like Clinton's song contest, his balloting process modeled democratic praxes in the realm of music (Figs. $8 \mathrm{~b} \& 8 \mathrm{c}$ ). ${ }^{83}$

In addition to engaging with the candidates' "official" campaign music, voters used Spotify to create their own campaign-themed playlists. ${ }^{84}$ Using the title "Barack Obamas," Spotify user jersmeister created a garden-variety classic-rock oriented Obama playlist (Fig. 9). User Jack Daniel, with his "Barack Obama vs. Mitt Romney" playlist, selected songs from various genres that feature battle themes. These include inner battles (Eminem's "Not Afraid"), fictional battles ("Justin Bieber vs. Beethoven" and "Darth Vader vs. Adolf Hitler"), and metaphorical battles ("Shark Attack" and "This Means War"). He also included tracks from blockbuster films that explore the same theme: man vs. machine (Terminator), man vs. monster

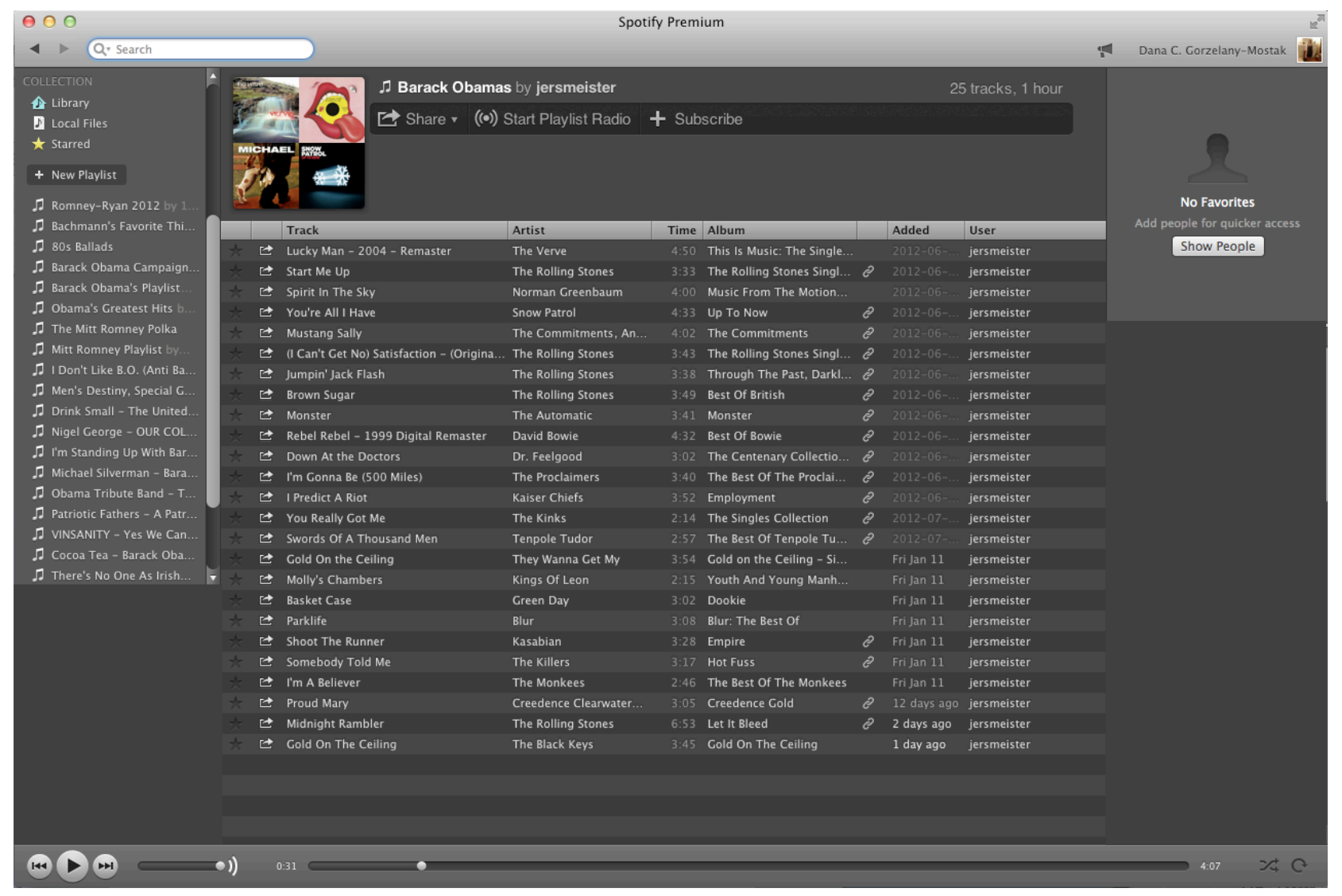

Figure 9: "Barack Obamas," a playlist by jersmeister (Spotify)

\footnotetext{
${ }^{83}$ Barack Obama Twitter page, May 7, 2012, https://twitter.com/BarackObama/status/199626751456976897.

${ }^{84}$ Spotify and iTunes offer many Obama-themed selections; some were created in response to his 2008 candidacy, whereas others were conceived as tributes after he assumed office. For musical offerings inspired by the re-election campaign, see on Spotify "I'm Gonna Win - (Barack Obama Campaign Rap)" by Alphacat; "Politics as Usual (Vote for Obama 2012) [feat. President Barack Obama]" by Doctor J, The Jinni \& Magic Man Mel; and “The Official ‘Obama 2012' Rap Song” by C.A.S.I.N.O
} 


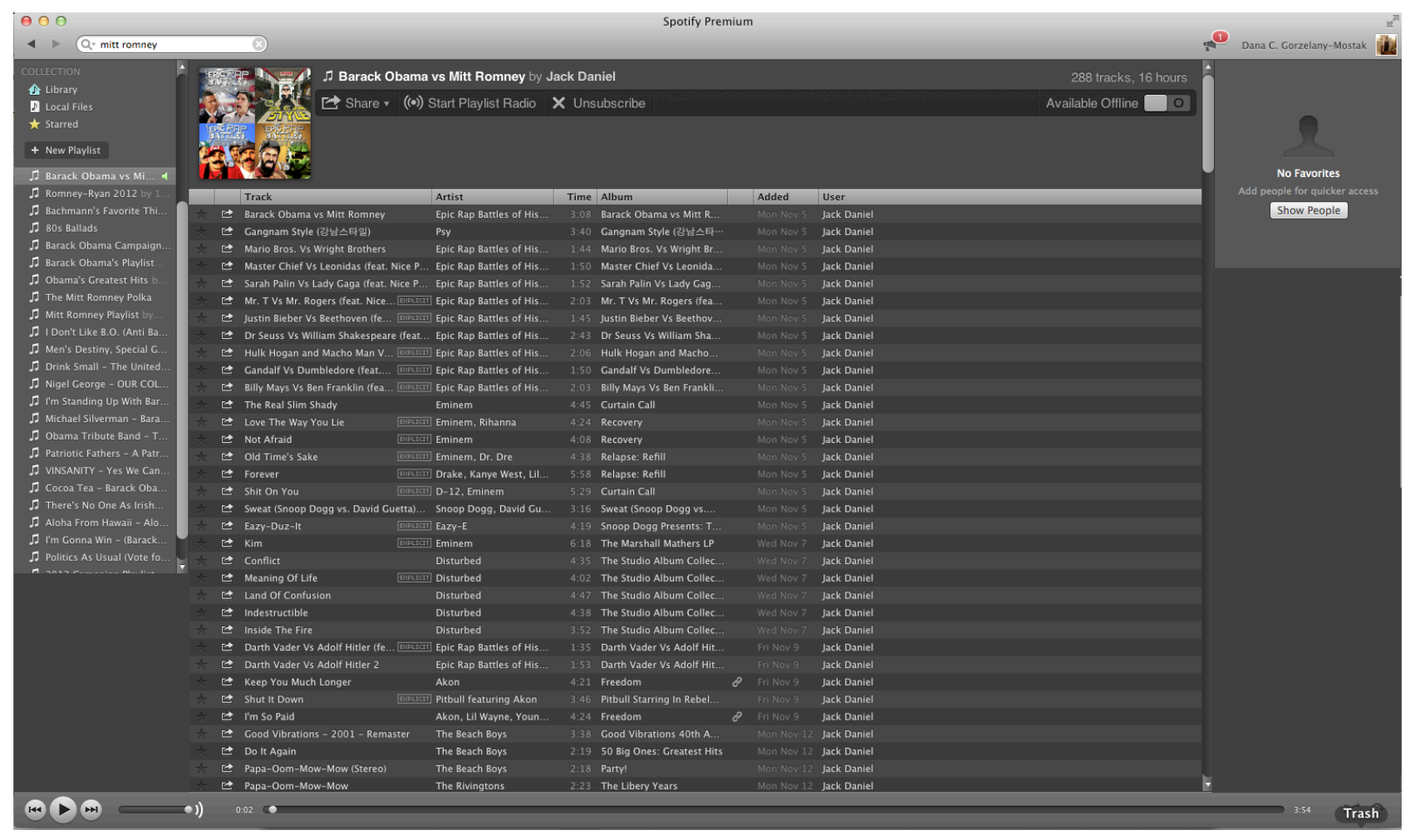

Figure 10: "Barack Obama vs. Mitt Romney,” a playlist by Jack Daniel (Spotify)

(Godzilla), and man vs. the supernatural (Poltergeist) (Fig. 10). ${ }^{85}$ Many puzzling choices made the list as well. (I am not sure which battle Beyoncé's "Single Ladies" refers to-battle of the sexes, perhaps?) The inclusion of the song "Barack Obama vs. Mitt Romney," and the playlist title of the same name suggest that the digital series Epic Rap Battles of History, created by Peter Shukoff and Lloyd Ahlquist, provided the inspiration for Jack Daniel's list. ${ }^{86}$

Journalists added their creative stamp to the soundscape as well. In August 2012, HuffPost Politics teamed up with Spotify to create its own red (leans Romney), blue (leans Obama), and yellow (tossup) playlists. On the website, users simply hovered their cursor over an area of the country to view a Huffington Post-curated playlist (Fig. 11a). An accompanying slide show, with witty and sometimes derisive commentary, allowed the user to find the news story that put the lists' creators "in the mood to sing" (Fig. 11b) ${ }^{87}$ On "Biden's Greatest Hits," for example, the Britney Spears song “Oops! . . I Did It Again” makes light of the vice president's accidental F-bomb slip on live television. Billy Joel's "Sleeping with the Television On" mocks him for appearing to doze off during an Obama speech at George Washington University. ${ }^{88}$ Other key players received the playlist treatment as well (e.g., Republican presidential

\footnotetext{
${ }^{85}$ Part of the list in Figure 10 is not included in the screenshot.

${ }^{86}$ The duo's YouTube channel features rap battles between various historical figures and pop culture icons. See Epic Rap Battles of History, http://epicrapbattlesofhistory.com/about.

${ }^{87}$ HuffPost Politics, "Spotify the Election," Huffington Post, August 27, 2012, http://www.huffingtonpost.com/2012/08/27/spotify-the-election_n 1834536.html.

${ }^{88}$ Chris Gentilviso, "Joe Biden DNC 2012 Speech: A Thursday Primetime Attraction," Huffington Post, September 6, 2012, http://www.huffingtonpost.com/2012/09/06/joe-biden-dnc-2012 n 1860010.html.
} 
candidate Michele Bachmann in "Michele Bachmann's Favorite Things"). Even before announcing their intentions to "Spotify the Election," HuffPost Politics featured politician-inspired lists. The news outlet's muses included New Jersey Governor Chris Christie ("Chris Christie's Greatest Hits"), Republican presidential candidate Rick Santorum ("Rick Santorum's Greatest Hits"), and former congresswoman Gabrielle Giffords ("Gabrielle Giffords' Road to Recovery"). As they did on other news sites, readers glossed over the playlists and created their own fictional lists in the comment sections. Whether serious or silly, these "statement playlists," to use Hagen's term, precipitated a broader dialogue as the public circulated the lists via Twitter, Facebook, and e-mail. ${ }^{89}$

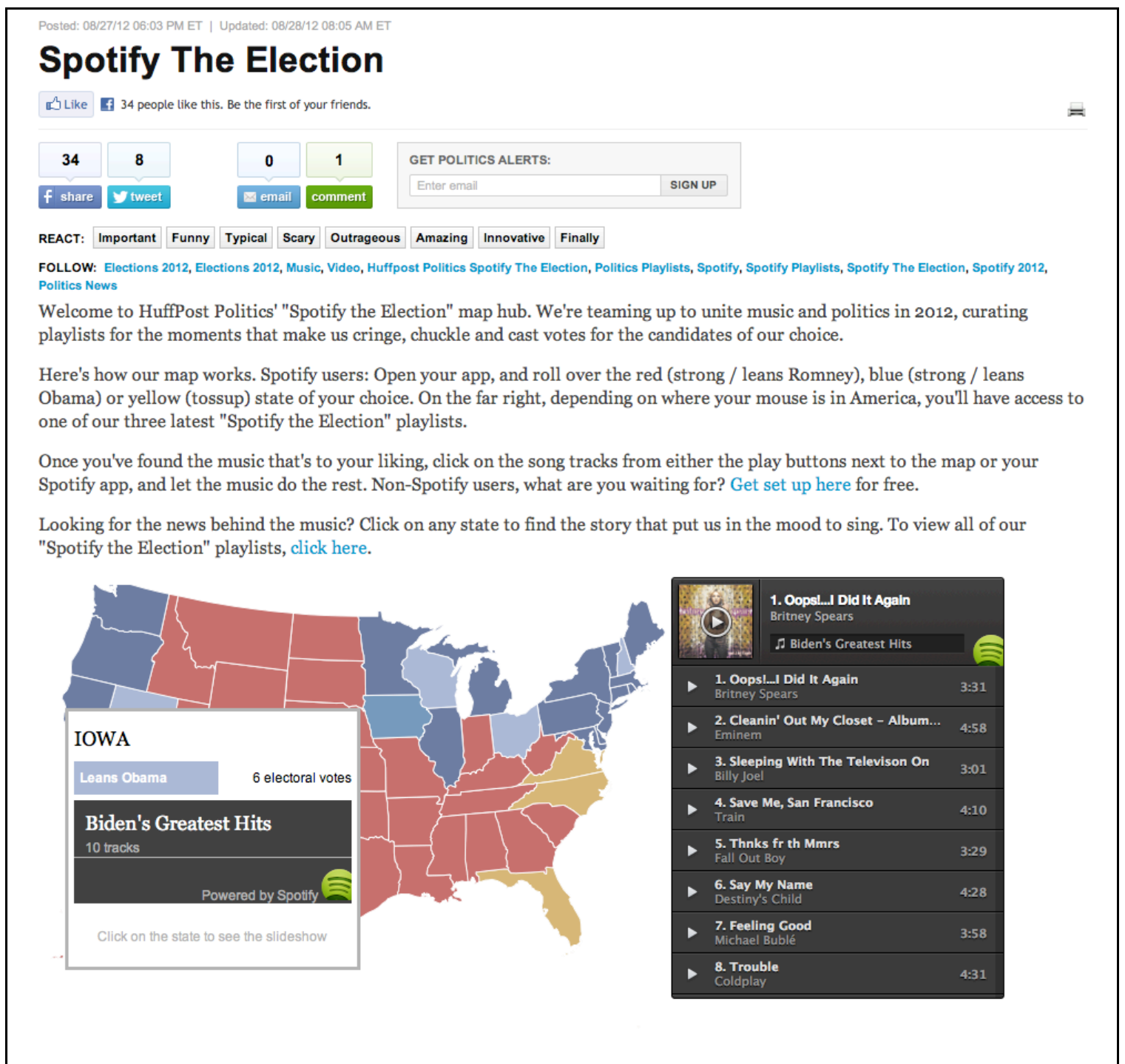

Figure 11a: "Biden's Greatest Hits," a playlist by HuffPost Politics

\footnotetext{
${ }^{89}$ Hagen, "Playlist Experience," 14-15.
} 


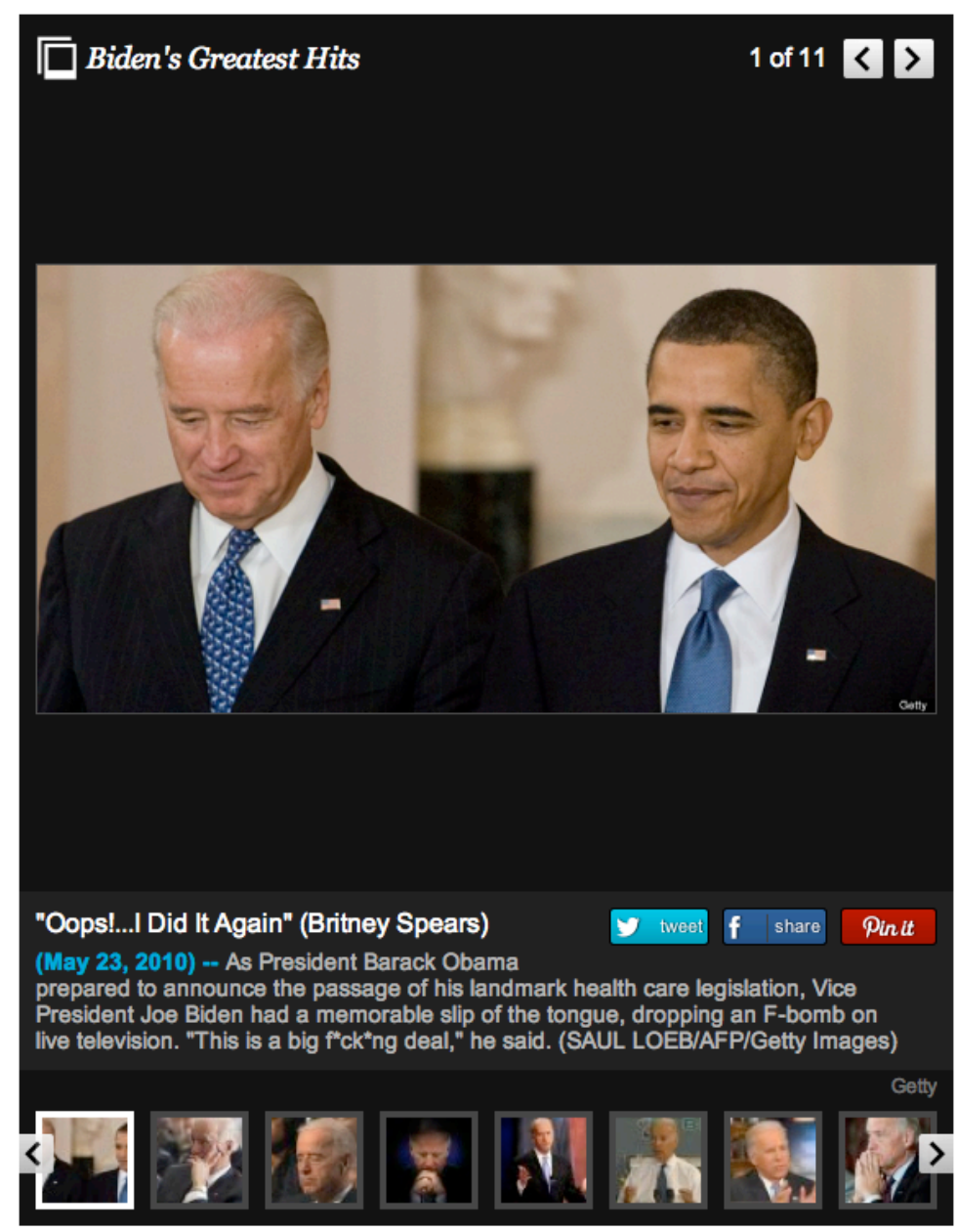

Figure 11b: "Biden's Greatest Hits," a slideshow by HuffPost Politics

\section{"Let's Keep House Music Out of the White House"}

Like the journalists at HuffPost Politics, who curated playlists "for the moments that make us cringe, chuckle and cast votes," comedy websites and late-night shows eagerly weighed in on the unfolding election and its motley cast of characters..$^{90}$ Using a campaign topic du jour (Romney's taxes) as its point of departure, the website CollegeHumor created a satirical video titled "Mitt Romney Won't Release His Spotify Playlist" in October of 2012. ${ }^{91}$ This "attack advertisement," paid for by the fictitious American Council for Presidents with Good Spotify Playlists, ingeniously establishes a parallel between the concealment of one's finances and the concealment of one's music preferences (Video 2).$^{92}$ The voiceover begins:

\footnotetext{
${ }^{90}$ HuffPost Politics, "Spotify the Election."

91 "Mitt Romney Won't Release His Spotify Playlist," directed by Matthew Pollock, produced by Jon Wolf, written by Brian Murphy, October 16, 2012, video clip, CollegeHumor, http://www.collegehumor.com/video/6836105/mitt-romney-wontrelease-his-spotify-playlist. The comedy website CollegeHumor features the site team's own content as well as content shared by its users.

${ }^{92}$ Michael Luo and Mike McIntire, “Offshore Tactics Helped Increase Romneys' Wealth,” New York Times, October 1, 2012, http://www.nytimes.com/2012/10/02/us/politics/bains-offshore-strategies-grew-romneys-wealth.html?hp\&_r=2\&. As I discussed above, Romney did release a Spotify playlist, so the list secrecy implied by the video really has no basis in reality.
} 
Mitt Romney refuses to release any of his tax returns before 2010. (thud) What are you trying to hide, Mitt? (thud) But the secrets don't end there. (gavel) Mitt Romney joined Spotify in April, but neglected to connect it to his Facebook until last month. What is Mitt Romney keeping from his Facebook friends? (thud)

The format of the video resembles that of a documentary, and at key points including the opening, it features the visual and aural rhetoric of the television attack advertisement. Ominous music underscores the images while thuds and gavel sounds punctuate the accusatory statements and unanswered questions posed by the narrator. The shift from a slow zoom in color to freeze-frame black and white images accentuates the "seriousness" of the message (Fig. 12). After some banter from commentators, the voiceover continues: "Mitt Romney has signed up for several Facebook accounts using foreign e-mail addresses. Should he be exempt from his friends making fun of him?” With this statement, the narrator hints at Romney's failure to disclose his tax information, but recasts the accusation in terms of list disclosure ("foreign e-mail addresses" stand in for "foreign banks"). Shortly thereafter, one reporter hosts a sit-down interview where the "candidate" states, "my musical preferences are a personal matter." This turn of phrase references the real Romney's rationale for withholding his tax returns: he did not want to disclose details regarding his tithing to the Mormon Church, a charitable act he describes as "a very personal thing between ourselves and our commitment to our God and to our church." 93

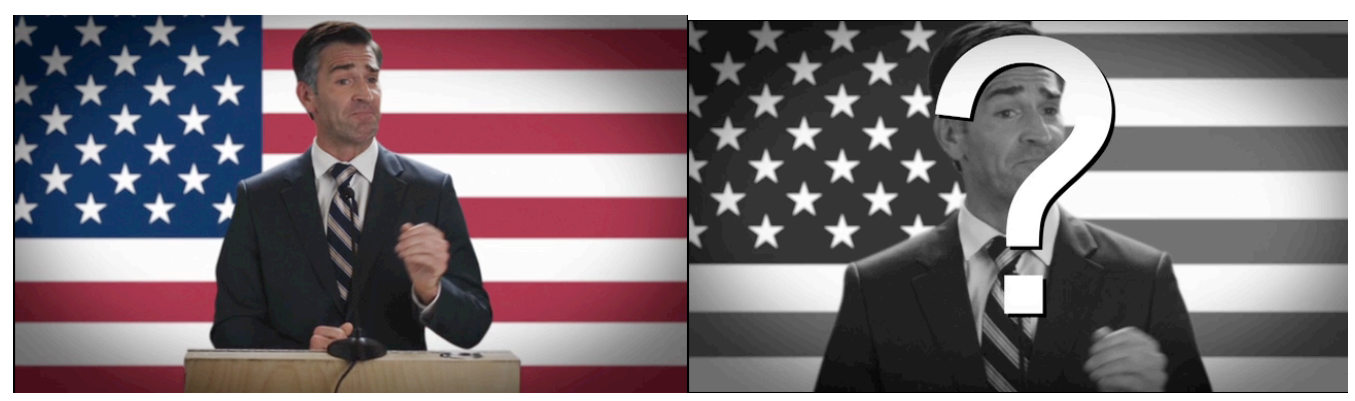

Figure 12: “Mitt Romney Won’t Release His Spotify Playlist”

\begin{abstract}
Video 2: "Mitt Romney Won't Release His Spotify Playlist," CollegeHumor
View at: http://dx.doi.org/10.3998/mp.9460447.0009.202
\end{abstract}

As the video unfolds, the commentators censure Romney for his refusal to disclose his Spotify playlist and insinuate that his concealment hides less than acceptable music tastes. They ponder his predilection for the Spin Doctors and Hootie \& the Blowfish, the songs "Bawitdaba" and "Bust a Move" ("but is he talking about Young MC's version, or the Glee version?"), and even the musical Cats. To make matters worse, his Spotify contains only 14\% indie rock (a reference to the average 14\% the real Romney paid in income taxes on his 2010 and 2011 earnings). ${ }^{94}$ Like Newman's attack on the 2008 McCain Blender list, the mock advertisement at times implies the fictional Romney's music tastes may be indicative of a

\footnotetext{
${ }^{93}$ Brian Montopoli, "Romney: My Mormon Tithing Should Be Private," CBS News, August 23, 2012, http://www.cbsnews.com/8301-503544 162-57499296-503544/romney-my-mormon-tithing-should-be-private.

${ }^{94}$ Jeanne Sahadi, "Romney Paid 14\% Effective Tax Rate in 2011," CNN, September 21, 2012, http://money.cnn.com/2012/09/21/pf/taxes/romney-tax-return/index.html.
} 
queer sensibility-Newman suggests Streisand and ABBA, CollegeHumor suggests the television juggernaut Glee and an Andrew Lloyd Webber musical. The subtle barbs directed at the candidate's manhood as evidenced by taste in music are particularly ironic considering the fact that his actual Spotify playlist included only one female artist and featured profoundly androcentric narratives. Taking a melodramatic turn at the end, the video closes with a reference to Lyndon B. Johnson's famous "Daisy" advertisement. Candidates be forewarned: bad taste in music may lead to Armageddon (Figs. 13a \& 13b; Video 3). ${ }^{95}$

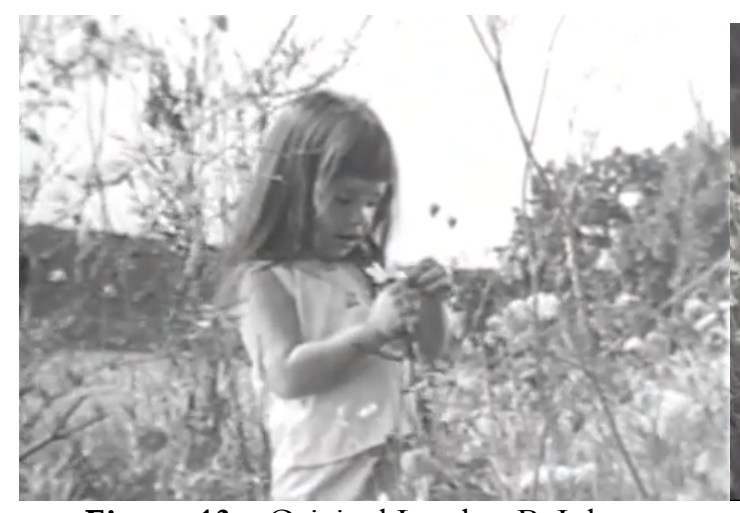

Figure 13a: Original Lyndon B. Johnson "Daisy" advertisement

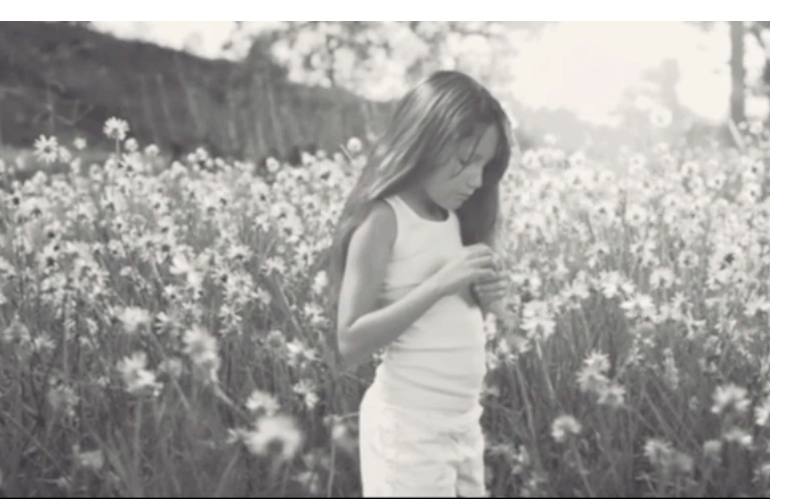

Figure 13b: Parody of Lyndon B. Johnson "Daisy" advertisement in "Mitt Romney Won't Release His Spotify Playlist"

Video 3: Lyndon B. Johnson "Daisy" advertisement (1964)

View at: http://dx.doi.org/10.3998/mp.9460447.0009.202

As the chatter surrounding playlists and this satirical video illustrate, the music and entertainment industries, press outlets, and individuals folded criticisms of candidates into narratives that explored the meanings attached to music preferences. The 2012 season premiere of Saturday Night Live opened with such a sketch, featuring Barack Obama and Mitt Romney impersonators (Fig. 14; Video 4). ${ }^{96}$ The sketch alternates between three scenes: (1) Obama (Jay Pharoah) assuring Ohio rally attendees that he is not anxious about the upcoming election (despite the economy, job market, and attacks on his foreign policy); (2) Paul Ryan responding to a sit-up gaffe (likely a spin on his false claim of an impressive marathon time); and (3) Romney (Jason Sudeikis) speaking at a town-hall-style meeting in Oklahoma. In the final minutes of the sketch, the impersonators give a nod to music-related campaign discourses:

\footnotetext{
${ }^{95}$ Democratic National Committee, "Peace Little Girl (Daisy),” created by Doyle Dane Bernbach: Aaron Erlich, Stan Lee, Sid Myers, and Tony Schwartz, September 7, 1964, video clip published at The Living Room Candidate: Presidential Campaign Commercials 1952-2012, Museum of the Moving Image, www.livingroomcandidate.org/commercials/1964/peace-little-girldaisy.

96 "Cold Opening: Obama vs. Romney," Saturday Night Live, season 38, episode 1, September 15, 2012, video clip, Yahoo! Screen, https://screen.yahoo.com/cold-opening-obama-vs-romney-000000349.html. For Ryan's response to the marathon time controversy, see Nick Wing, "Paul Ryan Explains Marathon Time Snafu: I Made Up What I Thought Was 'An Ordinary Time," Huffington Post, September 5, 2012, http://www.huffingtonpost.com/2012/09/05/paul-ryan-marathonlie n 1858384.html.
} 
BARACK OBAMA IMPERSONATOR: So America, I know you're not in love with me anymore. But I want you to know that my heart still beats for you, and I can prove it. [sung:] "I'm...I'm so in love with you." That was fun, right. So do you want that or this? [cuts to Mitt Romney]

MITT ROMNEY IMPERSONATOR: [sung:] E-i-e-i-o. [laughs] Hey how 'bout that? That was "Old MacDonald Had a Farm." Pretty, pretty, groovy song huh, sorry I didn't know all the animal noises. Hey, speaking of music, oh look at this, speaking of music right here. This guy looks like a young Lou Rawls, huh? See this gentleman right here? Ha! Who's Lou Rawls? Uh, he's an African American that looks just like you. I mean, no, not that I mean, I don't mean, uh hey, high five. Here you go. [raises hand] Oh, you don't have arms? Ok, um, there you go. [taps him on the forehead]
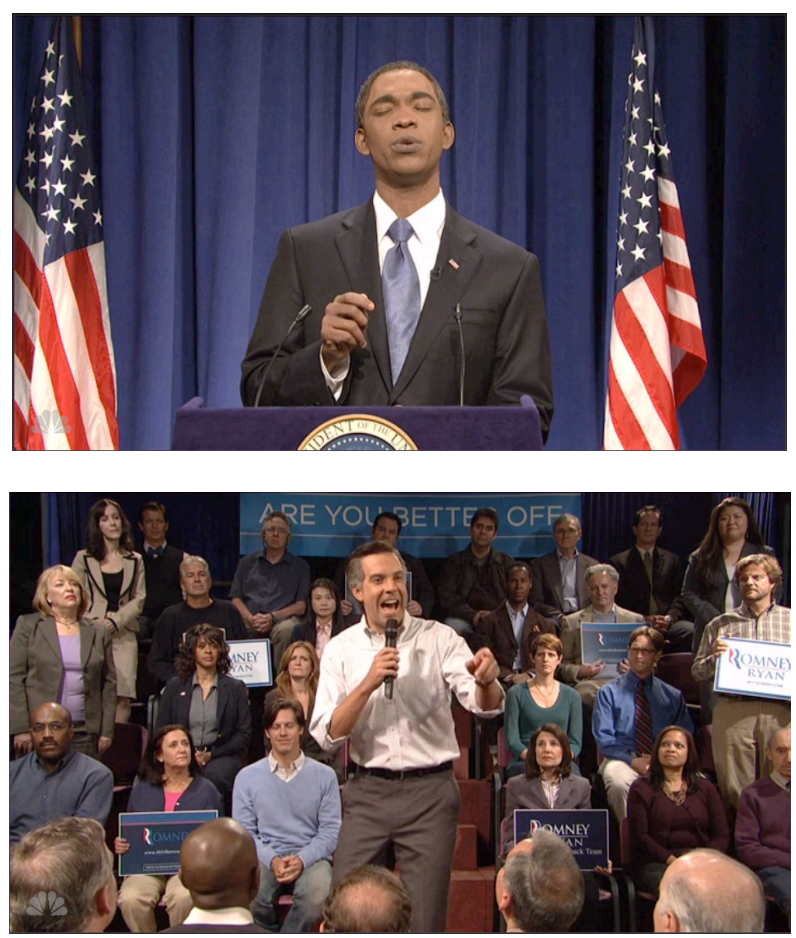

Figure 14: Obama and Romney impersonators, Saturday Night Live

Video 4: “Obama vs. Romney," Saturday Night Live (2012)

View at: http://dx.doi.org/10.3998/mp.9460447.0009.202

The Obama impersonator's performance of the Al Green classic "Let's Stay Together" parodies the real Obama's January 19 rendition at an Apollo Theater fundraiser. Shortly after the candidate crooned a few bars, the clip went viral, and digital sales of Green's song jumped 490 percent. Obama offered up the hook as a free ringtone download on his official website, and Rolling Stone created its own Spotify playlist titled "10 Songs Obama Should Sing Next" in response to the tribute. ${ }^{97}$ The iconic balladeer, who appeared on the stage at the same event, claimed the candidate "nailed" the performance, and the Huffington Post quipped, "Who knew the President would be a one-man stimulus package for the music

97 “President Obama Obama Sings 'Let’s Stay Together,” Rolling Stone, January 20, 2012, 
industry?" 98 In the sketch, Obama's soulful interruption trivializes the unresolved economic and security issues that he cited a moment earlier. Moreover, the song underscores the nonchalant, hubristic attitude he displays in the speech. While the song choice affirms his musical sophistication, its inappropriate placement in a weighty speech implies his policy is driven by passion and feel-good emotions rather than rationality and a cogent agenda. ${ }^{99}$

With parodic flair, the sketch makes light of Obama's contrived coolness and misplaced optimism, but the Republican candidate also gets his comeuppance. The Romney impersonator's performance of a juvenile song, "Old MacDonald Had a Farm," suggests he lacks both musical taste and sophistication. His description of the song as "groovy" - a rather anachronistic term and unfitting description for a children's ditty-drives this point home. Not surprisingly, the candidate's lack of cultural knowledge extends to the speech that follows: here, he singles out an armless black man in the audience who he thinks resembles old school R\&B singer Lou Rawls. Romney's misrecognition and the inappropriate gesture that follows (a high five directed towards an armless man) provide an interesting counterpoint to Obama's selfpresentation in real life and the Obama impersonator's impression in "reel" life. Obama forges hipness through an association with black cultural practices and affiliations with black celebrities. In the sketch, we see this through the fictional Obama's gestures as well as his Al Green tribute. After a quick cut to Paul Ryan clarifying his workout regimen, Obama casually brushes off his shoulder. The real Obama quite effectively deployed this gesture during his previous presidential campaign. In an April 2008 speech the day after a debate, he accused opponent Hillary Clinton of playing the textbook Washington game and responded to her attacks by physically brushing the metaphorical dirt off his shoulders, nonchalantly stating in African-American vernacular English, "You gotta expect it, uh and, you just gotta kinda let it, you know, that's what ya gotta do." With this gesture, which blogger Spencer Ackerman hyped as "perhaps the coolest subliminal cultural reference in the history of American politics," Obama acknowledged Jay Z's song "Dirt off Your Shoulder" (2004). ${ }^{100}$ The clip garnered a large YouTube audience, and users reworked it into audiovisual mashups. In the Saturday Night Live sketch, the subtlety of Obama's gesture heightens the awkwardness of Romney's gesture directed towards the physically handicapped man. Romney attempts to appropriate Obama's hipness strategy (by dropping his knowledge of a black performer), yet since he lacks the requisite cultural knowledge and sophisticated musical tastes, he fails miserably. At the same time, Romney's unsuccessful performance of hipness calls into question the similar strategies Obama wields to construct his own cultural and political authority. While the Saturday Night Live sketch offers a critique of both candidates, it also takes a jab at the public's preoccupation with campaign playlists, much in

http://www.rollingstone.com/politics/videos/obama-does-al-green-president-sings-lets-stay-together-20120120.

98 “President Obama Sings Al Green's 'Let's Stay Together,' Sales Jump 490\%," Huffington Post, January 27, 2012, http://www.huffingtonpost.com/2012/01/27/president-obama-sings-al-green-lets-stay-together-sales-jump_n_1236428.html. For Obama's performance, see “Raw Video: Obama Sings Al Green,” January 20, 2012, video clip, YouTube,

http://www.youtube.com/watch?v=y6uHR90Sq6k. In order to capitalize on the popularity of this sound bite, the candidate included the song on his Spotify playlist.

${ }^{99}$ Saturday Night Live was not the first to parody Obama's Al debut. In July 2012, Romney's camp released an attack advertisement titled "Political Payoffs and Middle Class Layoffs" on YouTube. Obama's performance of "Let's Stay Together" serves as the underscore while words flash on the screen, proclaiming him to be a supporter of the donor class rather than the middle class. Citing copyright infringement, music publisher BMG pulled the advertisement shortly after it appeared. See Judith Welikala, “BMG Pulls Romney Attack Ad over Obama Singing 'Let's Stay Together,” Time, July 18, 2012, http://newsfeed.time.com/2012/07/18/bmg-pulls-romney-attack-ad-over-obama-singing-lets-stay-together.

${ }^{100}$ For a report on this speech and the gesture, see Ari Melber, "Obama Meets Jay-Z in YouTube Mashup Slamming Clinton \& Debate," Huffington Post, April 17, 2008, http://www.huffingtonpost.com/ari-melber/obama-meets-jay-z-inyout b_97342.html. For footage of the speech, see “Obama Gets That Dirt off His Shoulder," April 17, 2008, video clip, YouTube, http://www.youtube.com/watch?v=kzXcNgCr0nk. 
the same manner as "Mitt Romney Won't Release His Spotify Playlist," an attack advertisement that warns voters to "keep house music out of the White House."

\section{“To Infinity ... and Beyond!”}

The popularity of digital playlisting platforms (especially Spotify), the proliferation of list-based sites (such as BuzzFeed, Listverse, and Ranker), and the flurry of online chatter surrounding presidential playlists attest to the public's continuing fascination with lists and list-making. In the age of Bill Clinton, strategist-designed playlists, such as those described by Begala, might be described as singular, stable, and comprised of pre-existing music, but by the 2008 and 2012 electoral cycles, candidate websites (to varying degrees) offered voters sophisticated participatory frameworks that allowed for user invention and interactivity, and these spilled over into the musical realm. ${ }^{101}$ Indeed, the tools of configurability expand the horizon of possibilities for individual campaign songs (as Michael Saffle's work in this issue suggests), as well as for campaign playlists. The 2012 candidates primarily relied on lists of pre-existing songs for their live events (such as the conventions James Deaville addresses in this issue), but web-based, usergenerated lists exposed voters to a continually fluctuating polyphonic soundtrack: songs such as Al Green's "Let's Stay Together" and Toby Keith's "Made in America" mingled with newly composed and campaignthemed parody songs, such as Crystal Lucas-Perry's "Take Us Forward (Obama 2012)" and CollegeHumor's “Mitt Romney Style," respectively. Dynamic, interactive, and didactic, the co-created lists of campaign 2012 and their surrounding discourses traversed multiple digital platforms, building an intertextual and intermedial electoral soundscape.

Much like the Billy Joel song cited in the opening, campaign-themed digital playlists embody Eco's "topos of ineffability." In other words, the Spotify format for both candidates, and in Obama's case, the "Supporter Picks" list recommendation form, position the playlists as open works, as entities that are incomplete and in need of completion. We may hear the beginning and end of the list as we stream it from our Spotify account, but at the same time, the image on the screen constantly forces us to imagine the unseen or omitted entries, what Eco refers to as the "etcetera" of the list. ${ }^{102}$ Taking on the appearance of a shop window, the visual presentation of a user account lists many albums, tracks, artists, playlists, and profiles, but at the same time, the arrows and scrollbars hint towards the additional content within the imaginary shop (Fig. 15). ${ }^{103}$ In his essay on collecting, Baudrillard argues, "pleasure springs from the fact that possession relies, on the one hand, upon the absolute singularity of each item-which means that it is equivalent to a human being, and eventually the subject himself-and, on the other, upon the possibility of envisaging a set or series of like items, in which is implied a prospect of limitless substitution and play." 104 With its slogan, "all music, all the time," Spotify points towards the ostensible infinity of its own contents. The Spotify layout offers a visual analogue to the literary device of asyndeton in that it maintains the illusion of unendingness by "remov[ing] the expectation of termination." 105 This apparently infinite quality places the 2012 Spotify playlists in the realm of Eco’s poetic list; poetic in the sense that the lists'

\footnotetext{
${ }^{101}$ Caroline E. Dadas, "Inventing the Election: Civic Participation and Presidential Candidates' Websites,” Computers and Composition 25, no. 4 (2008): 416-31.

${ }^{102}$ Eco, Infinity of Lists, 353-60.

${ }^{103}$ For more on consumer culture and the appearance of abundance, see Jean Baudrillard, “Consumer Society," in Selected Writings, $2^{\text {nd }}$ ed., ed. Mark Poster (Stanford: Stanford University Press, 2001), 32-59.

${ }^{104}$ Baudrillard, "System of Collecting," 10.

${ }^{105}$ Belknap, List, 28-30
} 
contents cannot be quantified and "[elude] our capacity for control and denomination." 106 The soundscapes of presidential campaigns overall assume this same infinite quality in the age of media convergence. Voters could recommend a song for Obama's rally playlist on Tumblr, download an Obamathemed mixtape from DatPiff, share Romney's Spotify playlist with their Facebook circle, comment on the appropriateness of "Born Free" as a campaign song after viewing Kid Rock's Romney rally performance on YouTube, compose their own digital mashup of Obama images with their playlist as the backtrack, and then tweet about the whole experience to their Twitterista followers on Twitter ... and the limitless play continues. Considering the many forums available for campaign music sharing and

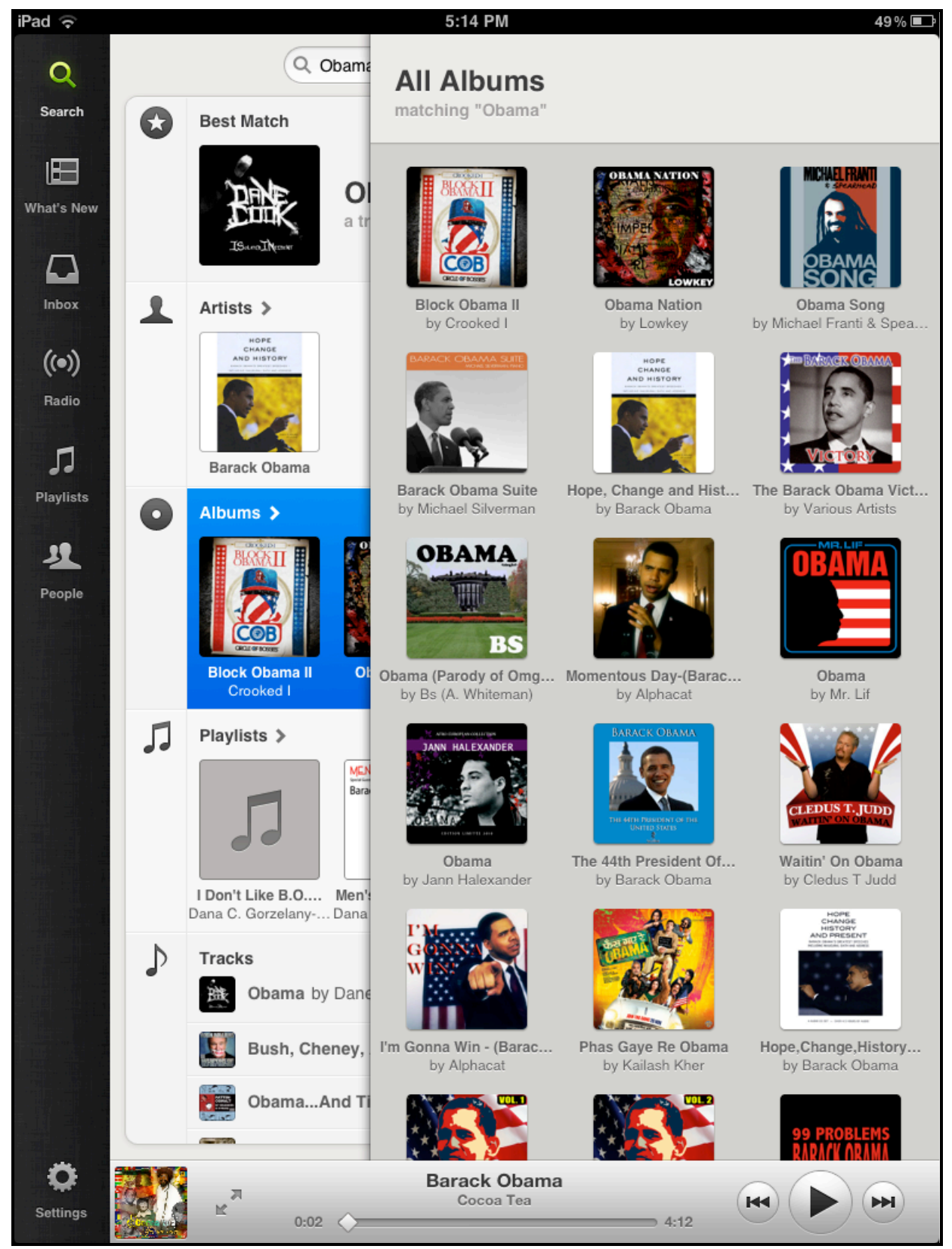

Figure 15: "Obama” search on Spotify (iPad)

${ }^{106}$ Eco, Infinity of Lists, 117-18. 
commentary, and the countless creative reinterpretations that make the search for an "original" near impossible, we might consider the campaign playlist a palimpsest of sorts (or to use a 2012 buzzword, an "Etch A Sketch") where boundaries, content, and signifier/signified remain in a perpetual state of flux. ${ }^{107}$

Ultimately, the creation and exchange of multiple campaign-centered lists forces us to expand our definitions of civic engagement and political participation in an age where music assumes a ubiquitous presence in the daily lives of citizens and where exchanges are increasingly tied to a screen (whether it be a laptop, $\mathrm{iPad}$, smartphone, or television). Indeed the ongoing process of musical reconfiguration that occurs in a decentralized, network society may disrupt the candidate's assertion of a distinct sonic signature or cogent musical identity, but perhaps the acts of playlist curation and exchange still have something to offer candidates and constituents.

What additional meanings do voters ascribe to the roles of curator and sharer, and how might such acts function in our quadrennial re-articulation of democracy? To address this question, I return to the progenitor of the digital playlist: the mixtape of the bygone analog age. ${ }^{108}$ Creative impulses aside, mixtapes explore murky terrain with regard to legality. (Is it fair use or copyright infringement?) ${ }^{109}$ In the 1970s and '80s, mixtapes circulated outside of mainstream distribution channels. Although some curators may have lacked an awareness of the potential legal ramifications and the music industry politics of the time, the creation and circulation of mixtapes was, to many, a declaration of artistic agency, a deliberate form of resistance to corporate control, or even a willful subversion of the capitalist system. Digital formats supplanted the mixtape to a certain extent by the late '90s, yet this cultural practice never really shed its subversive connotations or its legal woes. In the first decade of the twenty-first century, numerous digital playlist sites emerged only to later be taken offline on account of label lawsuits. ${ }^{110}$ Fast-forward to the present and playlist curation-even in a virtual space like Spotify where exchanges are legitimized and monetized-can be viewed as a liberating act that allows curators to assert their agency as they carve out their own sonic space and contribute to those of the individuals in their networks. Geoffrey O'Brien once called the mixtape "the most widely practiced American art form." ${ }^{\text {"111 }}$ If we accept this essayist's remark at face value, we might also surmise that campaign-related playlist activities, whatever form they may take, reaffirm the ideologies of democracy and the cultural values of the American melting pot. While these activities may not necessarily drive the public to the polls, or even lead to the true realization of democratic change, the accessibility of digital formats and technologies of interactivity indeed participate in maintaining the illusion of democracy.

\footnotetext{
${ }^{107}$ In March 2012, a CNN interviewer asked Romney's senior campaign advisor, Eric Fehrnstrom, if the politically moderate candidate felt forced into assuming a more conservative stance in the primary that might hurt his chances in November's general election. Fehrnstrom responded, "I think you hit a reset button for the fall campaign. Everything changes. It's almost like an Etch A Sketch. You can kind of shake it up, and we start all over again.” Republican rivals later used the advisor's remarks to buttress their contention that Romney shifts positions on the issues when it becomes politically advantageous. See Tom Cohen, "Romney’s Big Day Marred by Etch A Sketch Remark," CNN, March 22, 2012, http://www.cnn.com/2012/03/21/politics/campaign-wrap.

${ }^{108}$ Obama-themed mixtapes were widely circulated during the 2008 election. See Gosa, "Not Another Remix." (Mixtapes propelled hip-hop during its formative years, and to a certain extent, some hip-hop artists still rely on mixtapes to make their way to mainstream commercial success.)

${ }^{109}$ Here I am referring to homemade mixtapes, rather than the compilations sold through retail markets.

${ }^{110}$ Eliot Van Buskirk, "8 Best Ways to Share 'Mix Tapes,"” Wired, October 26, 2009, http://www.wired.com/2009/10/best-8ways-to-share-mix-tapes. For more on the legality of the creative selection and arrangement of pre-existing materials, see Sinnreich, Mashed Up, chap. 5.

${ }^{111}$ Oliver Howell, “Mixtapes and Heartbreak," Linn (blog), December 7, 2011, http://blogs.linn.co.uk/music/oliverhowell/mixtapes-and-heartbreak.php.
} 
Exchanges aside, the acts of creating and listening to campaign playlists may serve democracy in another manner. In recent years, scholars in the area of political communication have developed analytical models that explore the affective dimensions of media and the role that these media play in political decision making. ${ }^{12}$ Like the entertainment talk shows and fake news programs investigated by Dannagal G. Young, R. Lance Holbert, Kathleen Hall Jamieson, and Jeffrey P. Jones, campaign playlists and their related artefacts (e.g., CollegeHumor's “Mitt Romney Won't Release His Spotify Playlist”) are highly intertextual and frequently delve into the realm of satire and parody. Although entertainment media are unlikely to enhance political acumen or directly impact the voters' choice of candidate, confrontations with parody and satire "can effect more subtle outcomes like joy, enthusiasm, curiosity, and a sense of engagement in the popular political world (all of which can be deemed normatively positive for democracy)." 113 Returning to the idea of social currency, lists do not only generate buzz, they can also create for the voters meaningful experiences around the candidate's brand. ${ }^{114}$ As we move into the 2016 electoral cycle, candidates and constituents will continue to rewrite their roles in this changing political landscape, and as they do so, the playlist will likely continue to serve their needs in its capacity as identity builder, hipness indicator, crowd rouser, community sustainer, pleasure giver, democracy signifier, and to quote Eco, etcetera ...

\section{References}

Abbott, Philip. "A 'Long and Winding Road': Bill Clinton and the 1960s." Rhetoric E Public Affairs 9, no. 1 (2006): 1-20, http://dx.doi.org/10.1353/rap.2006.0019.

Adam, Katherine, and Charles Derber. The New Feminized Majority: How Democrats Can Change America with Women's Values. Boulder: Paradigm, 2008.

Attali, Jacques. Noise: The Political Economy of Music. Minneapolis: University of Minnesota Press, 1985.

Baudrillard, Jean. “Consumer Society.” In Selected Writings, 2nd ed., edited by Mark Poster, 32-59. Stanford: Stanford University Press, 2001.

—_. "The System of Collecting." In The Cultures of Collecting, edited by John Elsner and Roger Cardinal, 7-24. Cambridge, MA: Harvard University Press, 1994.

Beam, Christopher. "Barack Obama’s iTunes Playlist.” Trailhead (blog). Slate, January 26, 2008. http://www.slate.com/blogs/trailhead/2008/01/26/barack_obama_s_itunes_playlist.html.

Beard, Dave. “'Celebration’ and 'There’s Hope' on Obama’s Setlist.” Boston.com, January 5, 2008. http://www.boston.com/news/politics/politicalintelligence/2008/01/celebration_and.html.

\footnotetext{
${ }^{112}$ For more on voter behavior and emotional engagement, see Drew Westen, The Political Brain: The Role of Emotion in Deciding the Fate of the Nation (New York: PublicAffairs, 2007); and George Lakoff, The Political Mind: Why You Can't Understand 21st-Century Politics with an 18th-Century Brain (New York: Viking, 2008).

${ }^{113}$ Dannagal G. Young, R. Lance Holbert, and Kathleen Hall Jamieson, "Successful Practices for the Strategic Use of Political Parody and Satire: Lessons From the P6 Symposium and the 2012 Election Campaign," American Behavioral Scientist 58, no. 9 (2014): 1116; 1114-117. Also see Jeffrey P. Jones, "Parody, Performativity, and Play: The Reinvigoration of Citizenship through Political Satire," in A Companion to New Media Dynamics, ed. John Hartley, Jean Burgess, and Axel Bruns (Malden, MA: Wiley-Blackwell, 2013), 396-406; and Jonathan Gray, Jeffrey P. Jones, and Ethan Thompson, eds. Satire TV: Politics and Comedy in the Post-Network Era (New York: New York University Press, 2009).

${ }^{114}$ Vivaldi Partners, \$ocial Currency Study, 5.
} 
Belknap, Robert E. The List: The Uses and Pleasures of Cataloguing. New Haven: Yale University Press, 2004. http://dx.doi.org/10.12987/yale/9780300103830.001.0001.

Blender Blog. "Weird: John McCain Defends ABBA.” Blender, August 18, 2008. http://www.blender.com/2008/08/weird-john-mccain-defends-abba.

Blim, Richard Daniel. "Patchwork Nation: Collage, Music, and American Identity.” PhD diss., University of Michigan, 2013.

Boucher, Geoff. "Songs in the Key of Presidency." Los Angeles Times, October 11, 2000. http://articles.latimes.com/2000/oct/11/news/mn-34788/2.

Bourdieu, Pierre. Distinction: A Social Critique of the Judgement of Taste. Translated by Richard Nice. Cambridge, MA: Harvard University Press, 1984.

—_. "The Forms of Capital." In Handbook of Theory and Research for the Sociology of Education, edited by John G. Richardson, 241-58. New York: Greenwood, 1986.

Brown, Harley. "Slacker Radio CEO Duncan Orrell-Jones Wants to 'Reinvent Radio for a Post-YouTube Era."” Billboard, December 10, 2014. http://www.billboard.com/articles/news/6398461/slacker-radioceo-duncan-orwell-reinvent-radio-post-youtube.

Bull, Michael. "No Dead Air! The iPod and the Culture of Mobile Listening." Leisure Studies 24, no. 4 (2005): 343-55, http://dx.doi.org/10.1080/0261436052000330447.

Chang, Jeff. "Barack Obama: The Vibe Interview." Vibe, August 2007. http://www.thelavinagency.com/content/speakers/58/1212688601_chang-vibe.pdf.

Clayton, Dewey M. The Presidential Campaign of Barack Obama: A Critical Analysis of a Racially Transcendent Strategy. New York: Routledge, 2010.

Cohen, Michael A. “McCain's Fight Song.” Campaign Stops (blog). New York Times, October 19, 2008. http://campaignstops.blogs.nytimes.com/2008/10/19/mccains-fight-song.

Cohen, Tom. "Romney’s Big Day Marred by Etch A Sketch Remark.” CNN, March 22, 2012. http:/www.cnn.com/2012/03/21/politics/campaign-wrap.

Coplon, Jon. "White House DJ Battle.” Blender, July 30, 2008. https://web.archive.org/web/20080814151724/http://www.blender.com/WhiteHouseDJBattle/articles 39518.aspx.

Costa, Robert. "Songs for Campaign Seasons Past and Present." Wall Street Journal, October 2, 2008. http://online.wsj.com/article/SB122290103509796055.html.

Cursio, Matthew J. "Born To Be Used in the USA: An Alternative Avenue for Evaluating Politicians' Unauthorized Use of Original Musical Performances on the Campaign Trail." Villanova Sports $\mathcal{E}$ Entertainment Law Journal 18 (2011): 317-71.

Dadas, Caroline E. "Inventing the Election: Civic Participation and Presidential Candidates' Websites." Computers and Composition 25, no. 4 (2008): 416-31, http://dx.doi.org/10.1016/j.compcom.2008.05.004.

DeNora, Tia. Music in Everyday Life. Cambridge: Cambridge University Press, 2000. http://dx.doi.org/10.1017/CBO9780511489433.

Dewberry, David R., and Jonathan H. Millen. "Music as Rhetoric: Music in the 2012 Presidential Campaign." In Studies of Communication in the 2012 Presidential Campaign, edited by Robert E. Denton Jr., 175-94. Lanham, MD: Lexington, 2014.

Eco, Umberto. The Infinity of Lists: From Homer to Joyce. London: MacLehose, 2009. 
Edwards-Levy, Ariel. “Mitt Romney's Spotify Playlist.” Huffington Post, March 9, 2012. http://www.huffingtonpost.com/2012/03/09/mitt-romneys-spotify-play_n_1335839.html.

Essmeier, Trevor. "Spotify: Pioneers in Cloud Technology." Fresh Consulting website, September 23, 2011. http://freshconsulting.com/spotify-pioneers-in-cloud-technology.

Finn, Natalie. “Another Rocky Song Choice for John McCain.” E! Online, October 14, 2008. http://www.eonline.com/news/63813/another-rocky-song-choice-for-john-mccain.

Forman, Murray. "Conscious Hip-Hop, Change, and the Obama Era." American Studies Journal 54 (2010). http://asjournal.zusas.uni-halle.de/179.html.

Frith, Simon. Sound Effects: Youth, Leisure, and the Politics of Rock 'n' Roll. New York: Pantheon, 1981.

Gentilviso, Chris. "Joe Biden DNC 2012 Speech: A Thursday Primetime Attraction. Huffington Post, September 6, 2012. http://www.huffingtonpost.com/2012/09/06/joe-biden-dnc2012_n_1860010.html.

George, Kat. "President Obama Releases His 28 Song Campaign Playlist on Spotify." VH1.com, February 9, 2012. http://www.vh1.com/music/tuner/2012-02-09/president-obama-releases-a-28-song-strongcampaign-playlist-on-spotify.

Gilbert, Jason. “Barack Obama’s Spotify Playlist Reveals Love For No Doubt, Wilco.” Huffington Post, February 9, 2012. http://www.huffingtonpost.com/2012/02/09/barack-obama-spotifyplaylist_n_1266372.html.

___ "Obama's Spotify Playlist for 2012 Campaign: President Asks Voters to Soundtrack the Election." Huffington Post, May 4, 2012. http://www.huffingtonpost.com/2012/05/04/obama-spotify2012_n_1478026.html.

Gilpin, Dawn R. "Working in the Twittersphere: Microblogging as Professional Identity Construction." In A Networked Self: Identity, Community and Culture on Social Network Sites, edited by Zizi Papacharissi, 232-50. New York: Routledge, 2011.

Gorzelany-Mostak, Dana C. "Pre-existing Music in United States Presidential Campaigns, 1972-2012.” PhD diss., McGill University, 2013.

Gosa, Travis L. “'The Audacity of Dope': Rap Music, Race, and the Obama Presidency.” In The Iconic Obama, 2007-2009: Essays on Media Representations of the Candidate and New President, edited by Nicholas A. Yanes and Derrais Carter, 85-96. Jefferson, NC: McFarland, 2012.

_- "Not Another Remix: How Obama Became the First Hip-Hop President." Journal of Popular Music Studies 22, no. 4 (2010): 389-415, http://dx.doi.org/10.1111/j.1533-1598.2010.01252.x.

Gray, Jonathan, Jeffrey P. Jones, and Ethan Thompson, eds. Satire TV: Politics and Comedy in the PostNetwork Era. New York: New York University Press, 2009.

Hagen, Anja Nylund. “The Playlist Experience: Personal Playlists in Music Streaming Services.” Popular Music and Society (2015): 1-21, http://dx.doi.org/10.1080/03007766.2015.1021174.

Hamby, Peter. "Barack Obama Gets Name-Dropped in Hip-Hop.” CNN, August 17, 2007. . "McCain Rises to ABBA's Defense." CNN Political Ticker (blog). CNN, August 15, 2008. http://politicalticker.blogs.cnn.com/2008/08/15/mccain-rises-to-abbas-defense.

Hartley, John. "Silly Citizenship." Critical Discourse Studies 7, no. 4 (2010): 233-48, http://dx.doi.org/10.1080/17405904.2010.511826.

Hohmann, James. “Mitt Romney's Campaign Rally Playlist.” CLICK (blog). Politico, October 30, 2012. http://www.politico.com/blogs/click/2012/10/mitt-romneys-campaign-rally-play-list-147738.html. 
Howell, Oliver. “Mixtapes and Heartbreak.” Linn (blog), December 7, 2011. http://blogs.linn.co.uk/music/oliver-howell/mixtapes-and-heartbreak.php.

Huffington Post. “President Obama Sings Al Green's 'Let’s Stay Together,' Sales Jump 490\%.” January 27, 2012. http://www.huffingtonpost.com/2012/01/27/president-obama-sings-al-green-lets-staytogether-sales-jump_n_1236428.html.

HuffPost Politics. "Spotify the Election." Huffington Post, August 27, 2012. http://www.huffingtonpost.com/2012/08/27/spotify-the-election_n_1834536.html.

Jeffries, Michael P. "Obama as Hip-Hop Icon.” Epilogue to Thug Life: Race, Gender, and the Meaning of HipHop, 199-206. Chicago: University of Chicago Press, 2011.

Jenkins, Henry. Convergence Culture: Where Old and New Media Collide. New York: New York University Press, 2006.

Jones, Jeffrey P. "Parody, Performativity, and Play: The Reinvigoration of Citizenship through Political Satire." In A Companion to New Media Dynamics, edited by John Hartley, Jean Burgess and Axel Bruns, 396-406. Malden, MA: Wiley-Blackwell, 2013. http://dx.doi.org/10.1002/9781118321607.ch27.

. "The Shadow Campaign in Popular Culture." In The 2004 Presidential Campaign: A Communication Perspective, edited by Robert E. Denton Jr., 195-216. Lanham: Rowman and Littlefield, 2005.

Jones, Steve. "Music That Moves: Popular Music, Distribution and Network Technologies." Cultural Studies 16, no. 2 (2002): 213-32, http://dx.doi.org/10.1080/09502380110107562.

Jordan, Matthew F. "Obama's iPod: Popular Music and the Perils of Postpolitical Populism." Popular Communication: The International Journal of Media and Culture 11, no. 2 (2013): 99-115.

Kaufman, Gil. "Barack Obama Reveals His iPod Playlist: Jay-Z, Bob Dylan, Bruce Springsteen ... And Sheryl Crow?" MTV.com, June 25, 2008. http://www.mtv.com/news/articles/1589934/whats-onobamas-ipod.jhtml.

___ "Jay-Z and President Obama: A Bromance History," MTV.com, September 19, 2012. http:/www.mtv.com/news/1694108/jay-z-obama-bromance.

Lakoff, George. The Political Mind: Why You Can't Understand 21st-Century Politics with an 18th-Century Brain. New York: Viking, 2008.

Levy, Steven. The Perfect Thing: How the iPod Shuffles Commerce, Culture, and Coolness. New York: Simon and Schuster, 2006.

Luo, Michael, and Mike McIntire. "Offshore Tactics Helped Increase Romneys' Wealth." New York Times, October 1, 2012. http:/www.nytimes.com/2012/10/02/us/politics/bains-offshore-strategies-grewromneys-wealth.html?hp\&_r=2\&.

Marcus, Greil. Double Trouble: Bill Clinton and Elvis Presley in a Land of No Alternatives. New York: Picador, 2001.

___. "The Elvis Strategy." New York Times, October 27, 1992. http://www.nytimes.com/1992/10/27/opinion/the-elvis-strategy.html.

McCourt, Tom. "Collecting Music in the Digital Realm." Popular Music and Society 28, no. 2 (May 2005): 249-52, http://dx.doi.org/10.1080/03007760500045394.

Meizel, Katherine. Idolized: Music, Media, and Identity in American Idol. Bloomington, IN: Indiana University Press, 2011. 
Melber, Ari. "Obama Meets Jay-Z in YouTube Mashup Slamming Clinton \& Debate.” Huffington Post, April 17, 2008. http://www.huffingtonpost.com/ari-melber/obama-meets-jay-z-inyout_b_97342.html.

Michaels, Sean. "Foo Fighters Slam John McCain Over Use of Song.” Guardian, October 9, 2008. http:/www.theguardian.com/music/2008/oct/09/foo.fighters.slam.john.mccain.

Middleton, Richard. “From Me To You' Popular Music as Message.” In Studying Popular Music, edited by Richard Middleton, 172-246. Milton Keynes, UK: Open University Press, 1990.

___ "Introduction: Locating the Popular Music Text." In Reading Pop: Approaches to Textual Analysis in Popular Music, edited by Richard Middleton, 1-19. Oxford: Oxford University Press, 2000.

Miles, William. Songs, Odes, Glees, and Ballads: A Bibliography of American Presidential Campaign Songsters. New York: Greenwood, 1990.

Montopoli, Brian. "Romney: My Mormon Tithing Should Be Private." CBS News, August 23, 2012. http://www.cbsnews.com/8301-503544_162-57499296-503544/romney-my-mormon-tithingshould-be-private.

Nielson, Erik. "How Hip-Hop Fell Out of Love with Obama." Guardian, August 23, 2012. http:/www.theguardian.com/music/2012/aug/23/why-hip-hop-deserting-obama.

- “'My President is Black, My Lambo's Blue': The Obamafication of Rap?” Journal of Popular Music Studies 21, no. 4 (2009): 344-63, http://dx.doi.org/10.1111/j.1533-1598.2009.01207.x.

Oakes, Jason Lee. “Mitt’s Mix.” Winning Hearts E Ears (blog), September 19, 2012. http://heartsandears.wordpress.com/2012/09/19/mitts-mix.

Oldenburg, Ann. “Tom Morello Rages against Paul Ryan.” USA Today, August 18, 2012. http://content.usatoday.com/communities/entertainment/post/2012/08/tom-morello-rages-againstpaul-ryan/1\#.UjI-9Dn3B0s.

Oray, Patrick B. "Myth, Symbol, and the Branding of an American Presidency." In The Iconic Obama, 2007-2009: Essays on Media Representations of the Candidate and New President, edited by Nicholas A. Yanes and Derrais Carter, 28-42. Jefferson, NC: McFarland, 2012.

Parker, Suzi. “Mitt Romney’s ‘Binders Full of Women.” She The People (blog). Washington Post, October 17, 2012. http://www.washingtonpost.com/blogs/she-the-people/wp/2012/10/17/mitt-romneysbinders-full-of-women.

Parry-Giles, Shawn J., and Trevor Parry-Giles. Constructing Clinton: Hyperreality \& Presidential Image-Making in Postmodern Politics. New York: P. Lang, 2002.

Petridis, Alexis. "Power Play." Guardian, April 12, 2005. http://www.theguardian.com/music/2005/apr/13/usa.popandrock.

Pew Research Center. "Romney in a Word: 'Honest,' 'Businessman,' 'Rich.'” Pew Research Center, Washington, DC, August 29, 2012. http:/www.people-press.org/2012/08/29/romney-in-a-wordhonest-businessman-rich.

Phillips, Kate. “Clinton Seeks a Theme Tune.” The Caucus (blog). New York Times, May 16, 2007. http://thecaucus.blogs.nytimes.com/2007/05/16/clinton-seeks-a-themetune/? $\_$php $=$true\&_type $=$blogs\&_r $=0$.

Podlas, Kimberlianne. "Off the Campaign Trail and Into the Courthouse: Does a Political Candidate's Use of a Song Infringe on the Performer's Trademark?" Journal Of Broadcasting \& Electronic Media 59, no. 1 (2015): 41-56, http://dx.doi.org/10.1080/08838151.2014.998226. 
Rentfrow, Peter J., and Samuel D. Gosling. "The Do Re Mi’s of Everyday Life: The Structure and Personality Correlates of Music Preferences." Journal of Personality and Social Psychology 84, no. 6 (June 2003): 1236-56.

Richards, Chris. "The Mixed Bag of Obama’s Campaign Song Playlist.” Washington Post, February 9, 2012. http://www.washingtonpost.com/lifestyle/style/the-mixed-bag-of-obamas-campaign-songplaylist/2012/02/09/gIQAVCqX2Q_story.html.

Roeper, Richard. "Keep on Rockin' in the Free World: Gore, Bush Try to Get in Tune with Young Voters.” Chicago Sun-Times, October 29, 2000.

Rolling Stone. "President Obama Obama Sings 'Let’s Stay Together.” January 20, 2012. http://www.rollingstone.com/politics/videos/obama-does-al-green-president-sings-lets-staytogether-20120120.

Rutter, CJ. “P Diddy: 'Obama Owes Us!' Hip Hop Mogul Wants the President to Stand Up ...” TaleTela, February 1, 2011. http://www.taletela.com/news/4770/p-diddy-'obama-owes-us'.

Sahadi, Jeanne. "Romney Paid 14\% Effective Tax Rate in 2011." CNN, September 21, 2012. http://money.cnn.com/2012/09/21/pf/taxes/romney-tax-return/index.html.

Schoening, Benjamin S., and Eric T. Kasper. Don't Stop Thinking about the Music: The Politics of Songs and Musicians in Presidential Campaigns. Lanham, MD: Lexington, 2012.

Sinnreich, Aram. Mashed Up: Music, Technology, and the Rise of Configurable Culture. Amherst: University of Massachusetts Press, 2010.

Smith, Aaron. “The Internet's Role in Campaign 2008." Pew Research Center, Washington, DC, April 15, 2009. http://pewinternet.org/Reports/2009/6--The-Internets-Role-in-Campaign-2008.aspx.

Spence, Lester K. "Obama and the Future of Hip-hop Politics." In Stare in the Darkness: The Limits of Hiphop and Black Politics, 157-76. Minneapolis: University of Minnesota Press, 2011. http://dx.doi.org/10.5749/minnesota/9780816669875.003.0006.

Talev, Margaret. "Soul of the Obama Campaign Is in the Soundtrack." McClatchyDC.com, October 31, 2008. http://www.mcclatchydc.com/2008/10/31/55103/soul-of-the-obama-campaignis.html\#.UjHixDn3DfY.

Talev, Margaret, and Kate Andersen Brower. "Obama's Changing His Tune for 2012 Campaign's Mood Music.” Bloomberg Businessweek, February 14, 2012. http://www.businessweek.com/news/2012-0214/obama-s-changing-his-tune-for-2012-campaign-s-mood-music.html.

Ulloa, Nina. "iTunes Has 800 Million Accounts ... and 800 Million Credit Card Numbers ..." Digital Music News, April 24, 2014. http://www.digitalmusicnews.com/permalink/2014/04/24/itunes800m.

Van Buskirk, Eliot. "8 Best Ways to Share 'Mix Tapes." Wired, October 26, 2009. http://www.wired.com/2009/10/best-8-ways-to-share-mix-tapes.

Variety. "Lots of Campaign Songs, But Do They Win Votes?” August 29, 1956.

Vernallis, Carol. “Audiovisual Change: Viral Web Media and the Obama Campaign.” In Unruly Media: YouTube, Music Video, and the New Digital Cinema, 155-80. New York: Oxford University Press, 2013. http://dx.doi.org/10.1093/acprof:oso/9780199766994.001.0001.

Vivaldi Partners. \$ocial Currency Study, US 2010. New York: Vivaldi Partners, 2010. http://images.fastcompany.com/Vivald-iPartners_Social-Currency.pdf.

Voida, Amy, Rebecca E. Grinter, Nicolas Ducheneaut, W. Keith Edwards, and Mark W. Newman. "Listening In: Practices Surrounding iTunes Music Sharing." In CHI '05 Proceedings of the SIGCHI 
Conference on Human Factors in Computing Systems, 191-200. New York, NY: Association for Computing Machinery, 2005. http://dx.doi.org/10.1145/1054972.1054999.

Week staff. "Obama's Spotify Playlist: 7 Things It Says About His Campaign.” The Week, February 10, 2012. http://theweek.com/article/index/224286/obamas-spotify-playlist-7-things-it-says-about-hiscampaign.

Weigel, David. “Mitt Romney’s Spotify Playlist.” Weigel (blog). Slate, March 9, 2012. http://www.slate.com/blogs/weigel/2012/03/09/mitt_romney_s_spotify playlist.html.

Welikala, Judith. "BMG Pulls Romney Attack Ad over Obama Singing 'Let's Stay Together." Time, July 18, 2012. http://newsfeed.time.com/2012/07/18/bmg-pulls-romney-attack-ad-over-obama-singinglets-stay-together.

Wenner, Jann S. “A Conversation With Barack Obama.” Rolling Stone, July 10-24, 2008. http://www.jannswenner.com/Archives/Barack_Obama.aspx.

Westen, Drew. The Political Brain: The Role of Emotion in Deciding the Fate of the Nation. New York: PublicAffairs, 2007.

Williams, Raymond. Television: Technology and Cultural Form. New York: Schocken, 1975. http://dx.doi.org/10.4324/9780203450277.

Wing, Nick. "Paul Ryan Explains Marathon Time Snafu: I Made Up What I Thought Was 'An Ordinary Time." Huffington Post, September 5, 2012. http://www.huffingtonpost.com/2012/09/05/paul-ryanmarathon-lie_n_1858384.html.

Wolf, Jordan. "The Soundtrack to Barack Obama's 2012 Reelection Campaign.” Mic.com, February 9, 2012. http://mic.com/articles/4053/the-soundtrack-to-barack-obama-s-2012-reelection-campaign.

Wolfson, Howard. “Campaign Playlists.” New York Times, November 3, 2008. http://www.nytimes.com/2008/11/04/opinion/04wolfson.html.

Young, Dannagal G., R. Lance Holbert, and Kathleen Hall Jamieson, "Successful Practices for the Strategic Use of Political Parody and Satire: Lessons From the P6 Symposium and the 2012 Election Campaign." American Behavioral Scientist 58, no. 9 (2014): 1111-30. http://dx.doi.org/10.1177/0002764213506213.

Young, Liam Cole. “The List and/as Critical Environment: Un-'Black Boxing' Bob Mersereau's Top 100 Canadian Singles." Paper presented at the annual meeting of the International Association for the Study of Popular Music-Canada, Montreal, June 16-19, 2011.

___ "On Lists and Networks: An Archaeology of Form." Amodern 2: Network Archaeology (2013). http://amodern.net/article/on-lists-and-networks.

___ "Un-Black Boxing the List: Knowledge, Materiality, and Form." Canadian Journal of Communication 38, no. 4 (2013): 497-516.

\section{Websites}

4president. http://www.4president.org [archived presidential campaign websites].

Barack Obama Tumblr Page. http://barackobama.tumblr.com.

Barack Obama Twitter Page. https://twitter.com/BarackObama.

DatPiff. http://www.datpiff.com.

Epic Rap Battles of History. http://epicrapbattlesofhistory.com. 
Hillary for President Website. http://www.hillaryclinton.com.

Listology. http://listology.com.

Listverse. http://listverse.com.

Mitt Romney Twitter Page. https://twitter.com/MittRomney.

Ranker. http://www.ranker.com.

Spotify. https://www.spotify.com/us.

8tracks. http://8tracks.com.

\section{Audiovisual Materials}

"Cold Opening: Obama vs. Romney." Saturday Night Live. Season 38, episode 1. Yahoo! Screen video clip. September 15, 2012. https://screen.yahoo.com/cold-opening-obama-vs-romney-000000349.html.

Democratic National Committee. "Peace Little Girl (Daisy)." Created by Doyle Dane Bernbach: Aaron Erlich, Stan Lee, Sid Myers, and Tony Schwartz. September 7, 1964. Video clip posted at The Living Room Candidate: Presidential Campaign Commercials 1952-2012, Museum of the Moving Image, 2012. http://www.livingroomcandidate.org/commercials/1964/peace-little-girl-daisy.

"Hillary Clinton Sings National Anthem.” YouTube video clip. Posted by “gohillary08org," April 24, 2007. http://www.youtube.com/watch?v=KQYIHQvhIk0.

“Mitt Romney Won't Release His Spotify Playlist." Directed by Matthew Pollock. Produced by Jon Wolf. Written by Brian Murphy. CollegeHumor video clip. October 16, 2012. http://www.collegehumor.com/video/6836105/mitt-romney-wont-release-his-spotify-playlist.

"Music Picks from Obama, McCain." All Things Considered. NPR. Hosted by Robert Siegel and Melissa Block. August 12, 2008. http://www.npr.org/templates/story/story.php?storyId=93540755.

Neal, Mark Anthony. "Obama Hip Hop: From Mixtapes to Mainstream.” Interview with Liane Hansen. Weekend Edition Sunday. NPR. November 7, 2008. http://www.npr.org/templates/story/story.php?storyId=96748462.

"Obama Gets That Dirt off His Shoulder." YouTube video clip. Posted by "trainwreck politics," April 17, 2008. http://www.youtube.com/watch?v=kzXcNgCr0nk.

"Pick My Campaign Song: Round 2." Hillary for President video clip. May 24, 2012. http://web.archive.org/web/20070530183843/http://www.hillaryclinton.com/action/spotlight/?sc=8.

"Raw Video: Obama Sings Al Green." YouTube video clip. Posted by Associated Press, January 20, 2012. http://www.youtube.com/watch?v=y6uHR90Sq6k. 


\begin{abstract}
During the 2008 and 2012 electoral cycles, the music preferences of presidential candidates became the subject of endless commentary, critique, and consternation. While "a little musical priming," to use Irving Berlin's words, has been par for the course at least since the 1840s, candidates have increasingly relied on thoughtfully curated playlists of pre-existing songs in various campaign contexts, both live and online. Campaign playlists in their many manifestations function as a form of social currency for those who create, listen to, and share music in the twentyfirst century. This article investigates the functions of the list in music and music-related discourses, as well as the cultural work lists can perform during campaign season. After providing a handful of examples from early twentyfirst-century campaigns to illustrate these functions, I turn to Mitt Romney's and Barack Obama's use of playlists in 2012, focusing on Spotify and the public's reception to their respective engagements with music-sharing communities. To conclude, I consider the ways in which the campaign playlist serves as a tool for political communication, mobilization, and participation, and ponder its changing function in the 2.0 world.
\end{abstract}

